\title{
Policies towards Horizontal Inequalities in Post-Conflict Reconstruction
}

\section{Frances Stewart}

\author{
November 2006
}

\begin{abstract}
The design of policies towards countries where major conflicts have ended is becoming a major issue in the development agenda partly because of the numbers of countries where such policy is relevant and partly because their situation tends to be among the most desperate. This paper is concerned with one major requirement in reconstruction policies that is often overlooked: that is to design policies which will reduce the horizontal inequalities which are often a major source of conflict. If they do not, there will be a danger of renewed mobilization around them and a further outbreak of violence. The paper reviews the range of policies which would contribute to reducing horizontal inequalities. It also considers some political issues surrounding such policies, including potential political risks which can arise in adopting these types of policy.
\end{abstract}

Keywords: inequality, conflict, reconstruction, culture

JEL classification: D63, D74, O18, Z13

Copyright (C) UNU-WIDER 2006

*Director of Centre for Research on Inequality, Human Security and Ethnicity (CRISE) at the Department for International Development, Queen Elizabeth House, University of Oxford.

This study has been prepared within the UNU-WIDER project on 'Reconstruction in Conflict and Post-Conflict Societies’, directed by Tony Addison. The project was supported by the Finnish Ministry for Foreign Affairs.

UNU-WIDER gratefully acknowledges the financial contributions to the research programme by the governments of Denmark (Royal Ministry of Foreign Affairs), Finland (Ministry for Foreign Affairs), Norway (Royal Ministry of Foreign Affairs), Sweden (Swedish International Development Cooperation Agency-Sida) and the United Kingdom (Department for International Development).

ISSN 1810-2611 ISBN 92-9190-933-5 ISBN-13 978-92-9190-933-9 


\section{Acknowledgements}

I have received extremely useful research support from Emma Samman and Marcia Hartwell. I am very grateful to Corinne Caumartin for permission to draw on her paper in the section on Guatemala, and for her comments on an earlier draft. Luca Mancini prepared Figure 7.

The World Institute for Development Economics Research (WIDER) was established by the United Nations University (UNU) as its first research and training centre and started work in Helsinki, Finland in 1985. The Institute undertakes applied research and policy analysis on structural changes affecting the developing and transitional economies, provides a forum for the advocacy of policies leading to robust, equitable and environmentally sustainable growth, and promotes capacity strengthening and training in the field of economic and social policy making. Work is carried out by staff researchers and visiting scholars in Helsinki and through networks of collaborating scholars and institutions around the world. www.wider.unu.edu publications@wider.unu.edu

UNU World Institute for Development Economics Research (UNU-WIDER)

Katajanokanlaituri 6 B, 00160 Helsinki, Finland

Camera-ready typescript prepared by Lorraine Telfer-Taivainen at UNU-WIDER

The views expressed in this publication are those of the author(s). Publication does not imply endorsement by the Institute or the United Nations University, nor by the programme/project sponsors, of any of the views expressed. 


\section{Introduction}

The design of policies towards countries where major conflicts have ended is becoming a major issue in the development agenda partly because of the numbers of countries where such policy is relevant and partly because their situation tends to be among the most desperate. Today, for example, we have the Sudan, Afghanistan, Iraq, the Congo nearing the post-conflict stage, adding to the conflicts that ended with the end of the cold war, such as El Salvador, Nicaragua, Guatemala, Mozambique, and Angola. As is apparent from this list not all the conflicts have ended completely, and there is always a danger of recurrence. 1 In designing policy, therefore, it is essential to address the main factors that led to the conflict in the first place, as well as the more obvious requirements of demobilization, reconstructing the infrastructure and re-establishing conditions for economic growth.

This paper is concerned with one major requirement in reconstruction policies that is often overlooked: that is to design policies which will reduce the horizontal inequalities (HIs) which are often a major source of conflict. If they do not, and HIs are an important element behind mobilization for conflict, there will be a danger of renewed mobilization around them and a further outbreak of violence. The paper reviews the range of policies which would contribute to reducing HIs; it also considers some political issues surrounding such policies, including potential political risks which can arise in adopting these types of policy.

There are many economic and political causes of violent conflict-low incomes, high unemployment, and competition for resources, human rights abuses, etc.-some associated with horizontal inequalities, some not. Before appropriate reconstruction policies can be designed it is essential to understand the deep-rooted reasons for the conflict, which in many cases will go beyond HIs, and in some cases may not involve HIs at all. Thus the policies aimed at reducing HIs are not the only policies needed postconflict, and are not invariably relevant. The policies to be discussed below are relevant to situations where HIs are large and have been a significant factor underlying the conflict.

The paper is organized as follows. The next section will explore how HIs can contribute to conflict. On the basis of this analysis section 3 will consider the types of policies likely to reduce HIs. Section 4 will analyse how some of these policies have worked in practice, some successes and some problems. In section 5, we then consider how far such policies are currently incorporated in the reconstruction policy agenda, both on the

1 Econometric analysis of the causes of wars, invariably finds that the most consistent predictor of conflict in any country is having had a previous conflict. See, e.g. Auvinen and Nafziger (1999). 
basis of some general pronouncements and two examples-Mozambique and Guatemala. Section 6 will conclude.

\section{Causes of conflict: the role of HIs}

Horizontal inequalities are inequalities among groups with shared identities-identities formed by religion, ethnic ties or racial affiliations, or other salient ways that bind groups of people together. While many conflicts have a cultural dimension, i.e. the groups that fight perceive themselves as belonging to a common culture (ethnicity or religion) and are partly fighting for cultural autonomy, it is evident that cultural differences are not a sufficient explanation for conflict since many multicultural societies live together relatively peacefully, while others do so for decades and then conflict erupts. Indeed, Fearon and Laitin have estimated that from 1960-79 of all the potential ethnic conflicts in Africa (defined as occurring where different ethnic groups live side-by-side) only 0.01 per cent actually turned into conflict. We need, therefore, to go beyond cultural explanations of conflict to economic and political explanations. As Abner Cohen (1974: 94) argued:

Men may and do certainly joke about or ridicule the strange and bizarre customs of men from other ethnic groups, because these customs are different from their own. But they do not fight over such differences alone. When men do ... fight across ethnic lines it is nearly always the case that they fight over some fundamental issues concerning the distribution and exercise of power, whether economic, political, or both.

That is, cultural differences do not lead to violent conflict unless there are also major economic and/or political causes. The motivation of the participants is clearly at the heart of the roots of any violent situation. Many contemporary economists emphasize the pursuit of individual economic advantage as the prime force. But the majority of internal conflicts are organized group conflicts, not exclusively, or mainly, a matter of individuals committing random violence against others. What is involved is group mobilization with people with some shared identity or goals attacking others, in the name of the group. While young men may fight because they are unemployed and uneducated and have few other opportunities, they also generally fight out of loyalty to a group (sometimes an ideology or a cause), like the militia in Najaf, the Hutus in Rwanda, the Tamils in Sri Lanka, the Catholics in Northern Ireland and so on. Sometimes, indeed, the power of their beliefs or loyalties are so high that they are prepared to sacrifice their own interests-in the extreme including their lives-for the wider objectives of the group. Often governments are involved, dominated by one or other identity group, sometimes instigating attacks against other groups, sometimes 
being attacked. 2 In fact Holsti argues that state violence has more often than not been the initiating cause in recent conflicts (Holsti 2000).

In contemporary conflicts, group affiliations occur along a variety of different lines. In some, it is religious affiliation that provides the relevant binding and categorising identity (Northern Ireland; Moslems/Hindus in India, the Philippines, for example); in some it seems to be racial (Fiji; Darfur); in some it is ethnicity (Rwanda; North East India); in some clans are the main source of affiliation (e.g., Somalia) and in many there are overlapping distinctions, for example both ethnic and religious affiliations (as in Jos in Nigeria; and the Balkans), while class and ethnicity overlap in Central America and caste and ethnicity in Nepal. The salience of such identities for political purposes develops either where leaders choose to emphasize group difference for mobilization for political ends (for example, the Malaysian government choosing to emphasize Bumiputera identity; or indigenous movements in Ecuador and Bolivia) and/or the group is picked out by others for discrimination and sometimes physical violence (for example, the Jews throughout history; the Chinese in South East Asia; Northerners in Côte d'Ivoire).

Though group boundaries are generally indeterminate and people have multiple and fluid identities, leaders are able to emphasize (or even create) particular affiliations and call on these identities in mobilizing supporters. However, effective large scale group mobilization-particularly for violent actions-generally requires a basis in serious group grievances and ambitions. For leaders of such groups the main motivation may be political ambition; while followers, who also are concerned with their political representation, may be primarily motivated by grievance about the economic and social position of the group relative to others. Both leaders and followers may become strongly motivated where there are severe and consistent economic, social and political differences between culturally defined groups, or multidimensional HIs. It should be noted that it is not necessarily the relatively deprived who instigate violence. The privileged may do so, fearing loss of position. The prospect of possible loss of political power can act as a powerful motive for state-sponsored violence which occurs with the aim of suppressing opposition and maintaining power.

For simplification, we can categorize HIs into four areas: political participation; economic assets; incomes and employment; and social aspects. Each of these contain a number of elements. For example, political participation can occur at the level of the cabinet, the bureaucracy, the army and so on; economic assets comprise land, livestock, human capital etc. The four categories and the main elements are presented Table 1, which provides examples where particular HIs seem to have been instrumental in

2 It is often unclear which group initiated the action, but in reactions groups (including governments) can enhance and spiral the conflict, or can act to moderate or eliminate it. In many of the worst conflicts, governments are responsible for a spiralling effect (e.g. Guatemala; Aceh). 
provoking conflict. Relevant economic HIs vary according to the nature of the economy; e.g., land may be irrelevant in modern urban societies, but is clearly of paramount importance in Zimbabwe; access to employment and housing form significant HIs in developed economies, such as Northern Ireland; in rentier economies, control over such resources, directly or via the state, becomes an important source of group competition.

Table 1: Some examples of horizontal inequality in conflict situations

\begin{tabular}{|c|c|c|c|c|}
\hline \multirow[b]{2}{*}{ Dimensions } & & \multicolumn{2}{|c|}{ Economic } & \multirow[b]{2}{*}{$\begin{array}{l}\text { Social access } \\
\text { and situation }\end{array}$} \\
\hline & Political participation & Assets & $\begin{array}{l}\text { Employment } \\
\text { and incomes }\end{array}$ & \\
\hline \multirow{5}{*}{ 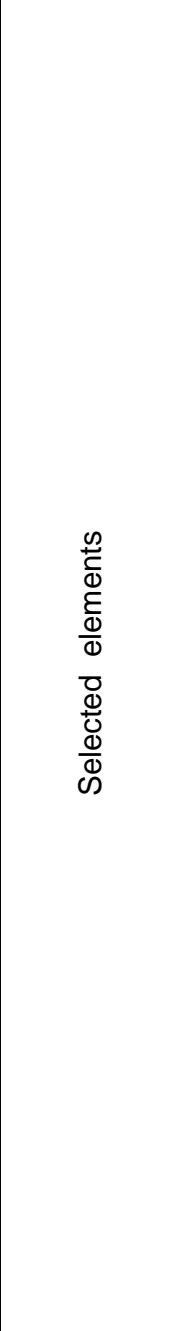 } & $\begin{array}{l}\text { Participation in govt } \\
\text { Fiji } \\
\text { Burundi } \\
\text { Bosnia \& Herzegovina } \\
\text { Uganda } \\
\text { Sri Lanka }\end{array}$ & $\begin{array}{l}\text { Land } \\
\text { Fiji } \\
\text { Cambodia } \\
\text { El Salvador } \\
\text { Haiti }\end{array}$ & $\begin{array}{l}\text { Incomes } \\
\text { Malaysia } \\
\text { South Africa } \\
\text { Fiji } \\
\text { Chiapas }\end{array}$ & $\begin{array}{l}\text { Education } \\
\text { Rwanda } \\
\text { Burundi } \\
\text { Haiti } \\
\text { South Africa } \\
\text { N. Uganda } \\
\text { Kosovo }\end{array}$ \\
\hline & & $\begin{array}{l}\text { Privately owned capital } \\
\text { Malaysia } \\
\text { South Africa } \\
\text { Burundi }\end{array}$ & $\begin{array}{l}\text { Govt employment } \\
\text { Sri Lanka } \\
\text { Fiji }\end{array}$ & $\begin{array}{l}\text { Health services } \\
\text { Burundi } \\
\text { N. Uganda } \\
\text { Chiapas }\end{array}$ \\
\hline & & $\begin{array}{l}\text { Govt infrastructure } \\
\text { Chiapas } \\
\text { Mexico } \\
\text { Burundi }\end{array}$ & $\begin{array}{l}\text { Private employment } \\
\text { Fiji } \\
\text { Uganda } \\
\text { Malaysia }\end{array}$ & $\begin{array}{l}\text { Safe water } \\
\text { N. Uganda } \\
\text { Chiapas }\end{array}$ \\
\hline & $\begin{array}{l}\text { Army/police } \\
\text { Fiji } \\
\text { Northern Ireland } \\
\text { Burundi } \\
\text { Kosovo }\end{array}$ & $\begin{array}{l}\text { Aid } \\
\text { Afghanistan } \\
\text { Sudan } \\
\text { Rwanda }\end{array}$ & $\begin{array}{l}\text { ‘Elite’ employment } \\
\text { South Africa } \\
\text { Fiji } \\
\text { Northern Ireland }\end{array}$ & $\begin{array}{l}\text { Housing } \\
\text { Northern Ireland }\end{array}$ \\
\hline & & $\begin{array}{l}\text { Natural resources } \\
\text { Liberia } \\
\text { Sierra Leone } \\
\text { Indonesia }\end{array}$ & $\begin{array}{l}\text { Unemployment } \\
\text { South Africa } \\
\text { Northern Ireland }\end{array}$ & $\begin{array}{l}\text { Poverty } \\
\text { Chiapas } \\
\text { Uganda } \\
\text { South Africa }\end{array}$ \\
\hline
\end{tabular}

Source: See text.

HIs may be spatially distributed-i.e., particular regions of a country are deprived (or privileged). In this case, HIs can lead to separatist claims - sometimes richer provinces seek separatism, not wanting to share their wealth (e.g., Biafra in Nigeria, or Aceh in Indonesia), and sometimes it is poorer regions, who feel exploited by the richer areas (e.g., Bangladesh and Eritrea). Different types of conflict emerge, however, where 
people from salient groups live in the same geographic area. In such cases, the deprived may seek political and economic rights or control over governmental institutions, or there can be attacks among groups without direct government involvement and pressure for ethnic cleansing. Appropriate policies differ in these different situations.

It is important to recognize that the normal economic policy package of liberalization and market forces is not generally sufficient to reduce HIs, or even to prevent them widening, while democratic institutions are often not sufficient to prevent horizontal inequalities arising on the political dimension. As far as economic HIs are concerned, this is because long-lasting privilege among some groups relative to others, puts them in a stronger position (with better education, more capital, etc.) to exploit the market. As far as political HIs are concerned, majoritarian democracies can discriminate against minorities, while even with 'shared' power at the top, inequalities may persist at lower levels. Inequalities in political power often lead to similar inequalities in economic and social dimensions. Biased distribution of government jobs, infrastructure and so on is common, with the group in power discriminating in its favour. For example, in Burundi in the 1990s, half of government investment went to Bujumbura and its vicinity, home of the elite Tutsi (Gaffney 2000). In some countries, the President and his coterie take a massive share of state resources for their private use-as, for example, the Duvaliers in Haiti and the Somoza family in Nicaragua (Lundahl 2000; Pastor and Boyce 2000). Research to date 3 suggests that HIs are more likely to provoke conflict when:

- They are durable (Tilly 1998). Clearly, temporary inequalities are much less provocative. According to Tilly, durability arises from groups trying to preserve their privileges, via exploitation and hoarding. Cumulative advantage is another cause of durability - for example, if a group has an advantage in income it is able to gain advantages in assets and earnings, which can lead to further educational advantages.

- Where HIs are not only sustained but widening over time.

- Group boundaries are relatively impermeable. If there is easy mobility across group boundaries, then inequalities can be overcome, at the individual level if not the group level, by changing identities.

- There are fairly large numbers in different groups. If the underprivileged group is very small, the chances of success through conflict may also be small (or the conflict can be easily suppressed) which makes serious conflict less likely. An important question concerns what numerical distribution of groups makes conflict most likely. Large numbers of small groups rarely are conflictual since no one group dominates and the small groups may develop peaceful coalitions. The coexistence of a large less economically privileged group with a significant but much smaller privileged group seems to provoke conflict, often initiated by the

3 In work at CRISE: see crise.ox.ac.uk 
larger group (examples are the Jews in Europe, the Chinese in South East Asia, the Tutsis in Africa, the Tamils in Sri Lanka.); 4

- HIs are consistent across dimensions. As noted, groups may be more inclined to rebel where there is lack of political power combined with economic deprivation. Political cooption of leaders can sustain peaceful coexistence even in the presence of strong economic HIs, as seems to have happened in Bolivia;

- Where aggregate incomes are stagnant or slow growing so that there is little or no improvement in absolute economic and social position of the deprived;

- Where groups are sufficiently cohesive for collective action to emerge;

- Where leaders emerge and are not co-opted into the ruling system; this is particularly likely to be the case where there are political HIs (or political exclusion of some groups); and

- Where the government is irresponsive (or, worse, proactively and violently repressive) and consequently there is no redress through peaceful means.

HIs are not, of course, the sole source of conflict.5 Other economic explanations of conflict include private incentives, arising particularly in the presence of natural resources where war provides opportunities of enrichment; individual grievances of various kind, particularly associated with low incomes, and high levels of poverty and unemployment; environmental pressures leading to conflicts over resources, especially land; and failure of the social contract to deliver public services, security and incomes. Each of these explanations has some statistical and case study support. Different conflicts have different explanations, while more than one hypothesis often appears to be relevant. For example, the north/south conflict in the Sudan was both an example of horizontal inequality (with the south being heavily deprived), and one of powerful private gains which perpetuated the struggle (Keen 1994). While environmental poverty has plausibly been argued to be a significant element in the conflict in Rwanda (André and Platteau 1996), horizontal inequalities were clearly also important.

Where HIs are a primary factor behind conflict, it is important to identify which of the many elements in HIs were critical. Hence one cannot devise a one size fits all solution. What one can do is to develop a general approach - to investigate and assess major HIs in all the three main dimensions, and then to develop suitable policies. Our research to date suggests that economic and social HIs represent a predisposing condition, such that deprived groups have strong grievances, but the simultaneous presence of major

\footnotetext{
4 These are the groups that Chua describes as 'market dominant minorities' (Chua 2003).

5 See Collier (2000); Homer-Dixon (1994); Nafziger and Auvinen (2002).
} 
political HIs makes violent conflict much more likely. ${ }^{6}$ Consequently, policies must address political as well as economic/social HIs.

The next section will review the sort of policies which would reduce HIs, with some examples of places where they have been applied. We look first at policies towards economic/social HIs and then at policies towards political HIs.

\section{Policies towards HIs}

Policies towards correcting HIs can be interpreted as a form of affirmative action. This is action taken towards the allocation of political and/or economic entitlements on the basis of membership of specific groups, for the purpose of increasing the specified groups' share of entitlements. The action generally covers the public sector and sometimes extends to private sector activity. Such action is directed at relatively disadvantaged groups. Similar action designed to improve the position of privileged groups (e.g., under apartheid) would be described as exclusionary rather than affirmative.

In devising policies, the first requirement is careful diagnosis to identify whether HIs were indeed a factor in the conflict, and which elements were particularly salient. It is essential, therefore, to gather data on groups' position, with respect to the major economic and political dimensions outlined above. In practice, data of this type is relatively rare except in countries where the importance of HIs is acknowledged and policies are being adopted towards them, such as in Malaysia or South Africa. In many cases, proxies will have to be used (geographic data is the most obvious proxy in cases where the groups are geographically located, but this, of course, won't help where there is geographic mixing). One important consideration is to avoid a situation in which the policies devised to correct HIs become a source of conflict as they arguably did in Sri Lanka. This issue will be discussed in the concluding section. Here I separate economic/social and political action towards HIs.

\subsection{Economic and social policies towards HIs}

Here the objective is to reduce economic and social HIs. But it is not always straightforward to decide what this means. For example: should one aim for equality of opportunities, of resource access or of outcomes? In the first case one would aim for 'an even playing field', i.e. that everyone faces the same opportunities, or there is no group discrimination. But this is not simple to define since groups with deep disadvantages which have accumulated over time are unable to use opportunities with the same efficiency and outcomes: for example, without any overt discrimination, the children of long-term privileged groups will do better in any competitive examinations, and so on.

6 This is well illustrated in recent developments in Cote d'Ivoire (see Langer 2005). 
Moreover, disadvantage has many aspects, some of which are quite hidden, e.g., job advertisements may be in newspapers which in principle are open to all but in practice are widely read by one group rather than another. Social networks and information about education, jobs, economic opportunities are often strongly group related, so what seems like a 'level playing field' is not. All sorts of implicit practices and job requirements (e.g., on language, time and place for job applications and so on) may favour one group against another. Therefore, the liberal philosophy of 'equal opportunities' is at best a necessary condition for advancing group equality. Another way of looking at this is to say that in addition to eliminating overt discrimination there is much implicit discrimination that must be addressed.

Equality of resource access - interpreted as equality of actual resource distribution, not 'opportunities' - is likely to get nearer to providing a genuine level playing field. This may still result in inequalities of outcomes, defined very broadly in terms of health, income per capita and educational achievements, 7 because the disadvantaged group is likely to be less efficient at using a particular set of assets in part because some assets are difficult to target, especially in the short-run, and are likely to remain unequal, such as features associated with upbringing, social capital etc. Hence for equality of outcomes one may need inequality in access to targetable assets, such as education, land, and capital. However, in most contexts large HIs prevail and as a first step achieving greater equality of actual asset access would represent important progress. Further policies to achieve equality of outcomes can follow in later years if asset equality has been achieved and inequality of outcomes persists.

One can distinguish three types of policy which may be adopted to achieve greater group equality in economic entitlements (although the distinctions are not watertight). First, one can change policies towards processes which are directly or indirectly discriminatory. Second, one can direct assistance to particular groups, e.g., training people for interviews, subsidising housing. Third, one can introduce targets and quotas for education, land distribution, financial and physical assets etc. The first type of policy is not so different from any set of policies to promote competition-although it involves a much more careful search for indirectly discriminatory policies than is usual. It is likely to be the most acceptable type of policy and can have a significant impact (this was a major part of the policy set adopted in Northern Ireland, see below). However, post-conflict reconstruction generally requires immediate action and impact, while process reform takes a while to have a significant impact. The second type of policy concerns the nature and distribution of public expenditure, often involving a redirection of expenditure across regions, or even neighbourhoods, as well as groups within them,

\footnotetext{
7 Equality of outcomes can be difficult to define: one surely does not want to aim for exact equality in every outcome (e.g. equal proportions of footballers, doctors, university professors, and so on, in relation to group numbers). Yet a racial or ethnic division of labour is at the root of many HIs so one does need to aim for some balance in representation in occupations, very broadly defined.
} 
and is in principle in the control of the government, but it may meet resistance from privileged areas or from the government itself representing privileged groups. This type of policy requires careful review of the implications of all public expenditure (and other relevant policies) for group distribution of benefits. It is noteworthy that this does not form an explicit consideration in the public expenditure reviews supported by the international donors, or that of most governments. The third type of policy (quotas, etc.) is most controversial and politically provocative. The third type is what many people mean when they talk of 'affirmative action' though affirmative action can be interpreted as including all three types of policy.

Where a major source of HIs is the public sector (education, employment, infrastructure) a good deal can be achieved through direct action by the government, if it wants to reduce HIs. HIs located in the private sector are more difficult to tackle, though all three types of policy will make a contribution.

Despite the fact that affirmative action (especially of the third type) smacks of government intervention and would, therefore, be against the spirit of the pro-market liberalization that dominates current policy making, there are many cases where it has been adopted in one way or another. These cases are instructive both for pointing to the variety of policies possible and some of their effects. Appendix Table A.1 summarizes a review of affirmative action in economic and social policies around the world showing how pervasive it is (see Appendix Table A1). The focus on the review was the third type (quotas, etc.) because these are most overt, although examples of other types were included. Such policies have been adopted both in the North (the USA, New Zealand, Northern Ireland) and the South (e.g., Fiji, India, Malaysia, South Africa and Sri Lanka).

The programmes reviewed are of two sorts: those introduced by disadvantaged majorities (e.g., Fiji, Malaysia, Namibia, South Africa and Sri Lanka) and those introduced by advantaged majorities for disadvantaged minorities (e.g., Brazil, India, Northern Ireland and the USA). The review of affirmative action, which I would not claim to be comprehensive, but does cover many examples, points to the range of potential policies for correcting HIs. They include policies towards:

Assets

- Policies to improve the group ownership of land via redistribution of government owned-land; forcible eviction; purchases; restrictions on ownership. Examples are from Malaysia; Zimbabwe; Fiji; Namibia;

- $\quad$ Policies towards the terms of privatization (Fiji);

_ $\quad$ Financial assets: bank regulations; subsidization; restrictions (Malaysia; South Africa);

- $\quad$ Credit allocation preferences (Fiji; Malaysia); 
- $\quad$ Preferential training (Brazil, New Zealand);

- $\quad$ Quotas for education (Malaysia, Sri Lanka, US);

- $\quad$ Public sector infrastructure (South Africa);

- Housing (Northern Ireland);

- $\quad$ In principle one might also have (though no examples were identified) policies to improve social capital (i.e. support for neighbourhoods associations, and networks outside the group).

Incomes and employment

- Employment policies, including public sector quotas (Malaysia, Sri Lanka, India) and requirement for balanced employment in the private sector (South Africa);

- $\quad$ Transfer payments: however, although there are many cases of age, disability and gender related transfers, no examples were identified of transfers according to ethnicity or religion or race.

Two successful country examples-Malaysia and Northern Ireland-illustrate how affirmative action can contribute to reducing social and economic HIs, helping to bring about and support peace.

Malaysia: a successful case of reducing economic and social HIs

As is now well-known, in 1971, following anti-Chinese riots, the New Economic Policy was introduced, with the aim of securing national unity by a two prong approach: 'to reduce and eventually eradicate poverty'; and 'to accelerate the process of restructuring Malaysian society to correct economic imbalance so as to reduce and eventually eliminate the identification of race with economic function' (Second Malaysian Plan 1971-75).

A variety of anti-poverty policies were adopted including policies to promote rural development and extend social services. As far as restructuring was concerned, the most significant policies:

- Aimed to expand Bumiputera share of capital ownership to 30 per cent.

- Aimed to settle 95 per cent of new lands on Malays.

- Introduced educational quotas for public institutions laid down, in line with population shares.

- Introduced credit policies which favoured Malays, with credit allocations and more favourable interest rates. 
As Figures 1 and 2 and Table 2 show, the policies were effective in reducing the differentials, but not in eliminating them. The application of the policies was much weakened from the mid-1980s, and since then there has been little progress in changing HIs, except in professional employment which may reflect earlier educational policies. Efficiency does not seem to have been adversely affected, since economic growth was rapid over this period. Evidence suggests that intra-group inequality did not increase during the NEP, but actually lessened, with the Gini for Malay incomes (peninsular) falling from 0.488 in 1979 to 0.428 in 1988, while the Gini for Chinese incomes fell from 0.470 to 0.400 over the same period. The distribution of Indian incomes also became more equal (Hashim 1997). The political objective does seem to have been achieved, as no serious anti-Chinese riots have occurred since 1969, even in the aftermath of the 1997 financial crisis while there were serious anti-Chinese violence elsewhere (Indonesia and Thailand). From a political perspective, the Chinese were represented in government via the alliance (UMNO) which has ruled Malaysia since 1955. However, most observers would concur that they had limited political power.

Figure 1: Incomes in Malaysia

Malaysia: Mean incomes relative to average

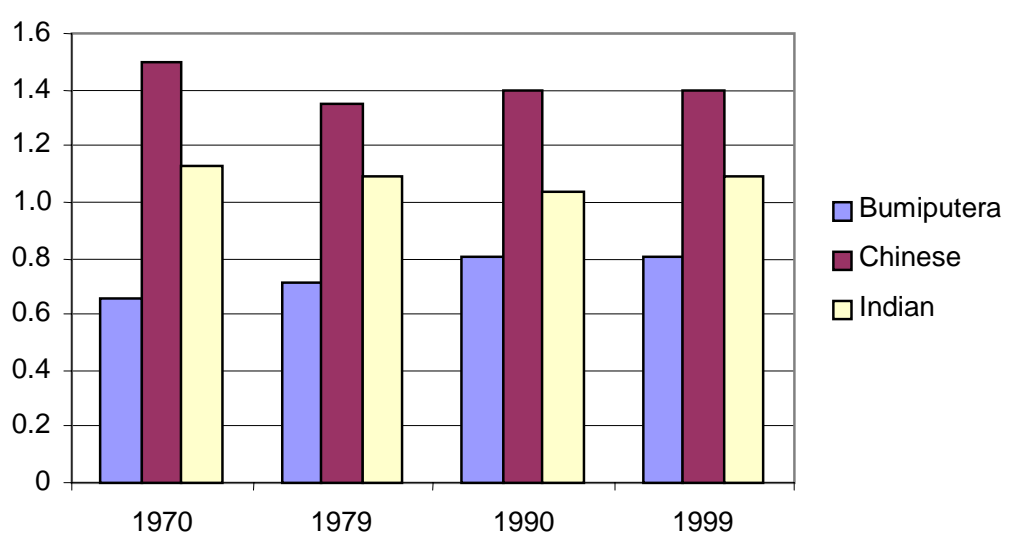

Figure 2: Capital ownership in Malaysia

Share of capital ownership as ratio of population share

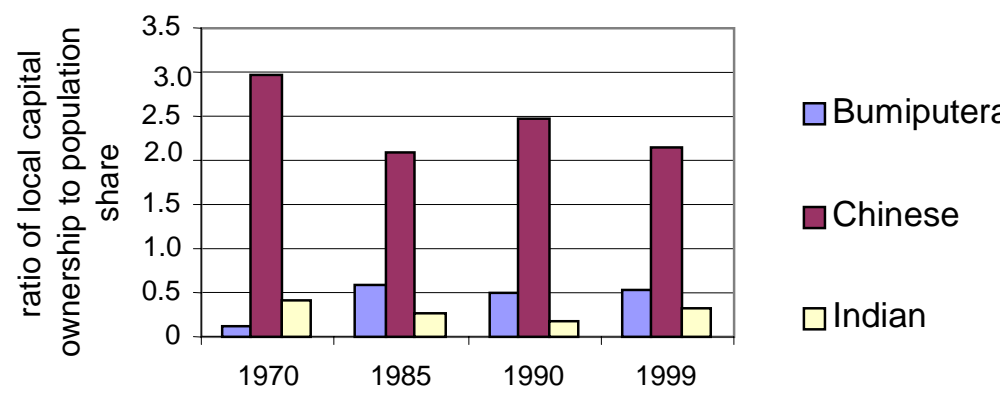


Table 2: Professional employment in Malaysia

\begin{tabular}{lcccc}
\hline & \multicolumn{4}{c}{ Share of total registered professionals as a ratio of population share, \% } \\
\cline { 2 - 5 } & 1970 & 1980 & 1990 & 1999 \\
\hline Bumiputera & 0.08 & 0.24 & 0.47 & 0.47 \\
Chinese & 2.03 & 2.12 & 1.86 & 1.80 \\
Indian & 2.91 & 2.18 & 1.65 & 1.94 \\
Standard deviation & 1.45 & 1.10 & 0.75 & 0.81 \\
\hline
\end{tabular}

Source: Jomo (2001).

Though widely criticized, the policies were accepted by the Chinese community probably because of the considerable economic opportunities they enjoyed, with rapidly growing incomes and continued differentials in their favour. The policies have also been criticized for leaving out the Indian community-although on average, they retained favourable differentials — and for the fact that the Bumiputera policy (sons of the soil) mainly favoured Peninsular Malays and not indigenous people in Sabah and Sarawak, such as the Orangi Asli.

\section{Northern Ireland}

In Northern Ireland, HIs have been large and persistent over all dimensions over a very long time period-indeed essentially since English Protestants first colonized Ireland in the fifteenth and sixteenth centuries. These sharp HIs-economic, social and politicalwere an important factor behind the outbreak of violence in the 1970s. From the late 1970s the British government and the European Union initiated policies to correct these inequalities. The success of these policies was probably one factor explaining why the Catholic community was prepared to stop violent action.

By the end of the nineteenth century Protestants controlled the vast bulk of the economic resources of east Ulster - the best of its land, its industrial and financial capital, commercial and business networks, industrial skills (Ruane and Todd 1996: 151). The division of the island, when the Republic of Ireland was created in 1922, ensured permanent political control and continued economic dominance by the Protestants in the province of Northern Ireland, where they formed the majority. Assessments indicate no narrowing of the gap between the communities from 1901 to 1951, with Catholics disadvantaged at every level (Hepburn 1983). Unemployment rates, for example, were consistently more than twice the rate among Catholics than Protestants; educational qualifications were substantially worse. In fact, there was some worsening of the Catholic position over the first three-quarters of the twentieth century, with a rising proportion of unskilled workers among Catholics and a falling proportion among Protestants and the relative unemployment ratios also appear to have worsened over this period (Ruane et al. 1996). 
Political inequalities were also large. For example, the Catholics with roughly 40 per cent of the population accounted for only 8 per cent of the membership of the Royal Ulster Constabulary (RUC), while devolution of power to the province meant that the majority Protestants were in permanent control. The consistency of the inequalities across political, economic and social dimensions - with most evidence suggesting little change in the first three-quarters of the twentieth century-provided fertile ground for the outbreak of the 'troubles' in the late 1960s.

From the late 1970s, the British government introduced a series of measures that worked to reduce economic and social HIs. The introduction of two Fair Employment Acts in 1976 and 1989 greatly reduced employment discrimination; and housing and education policy was geared to reduce differentials. The policies had a significant impact on His (see Figures 3, 4, and 5). Inequality in access to higher education was eliminated by the 1990s; inequality in incomes was reduced; the housing inequality was significantly reduced; and the employment profile and unemployment rates became more equal; even the imbalance in recruitment to the RUC was slowly being reversed. According to one observer 'It is unusual to find such a rate of social change within a generation. It is quite dramatic. In many areas Catholics have caught up with or surpassed Protestants’ (Osborne quoted by McKittrick 2004).

Figure 3: Horizontal Inequalities in Northern Ireland

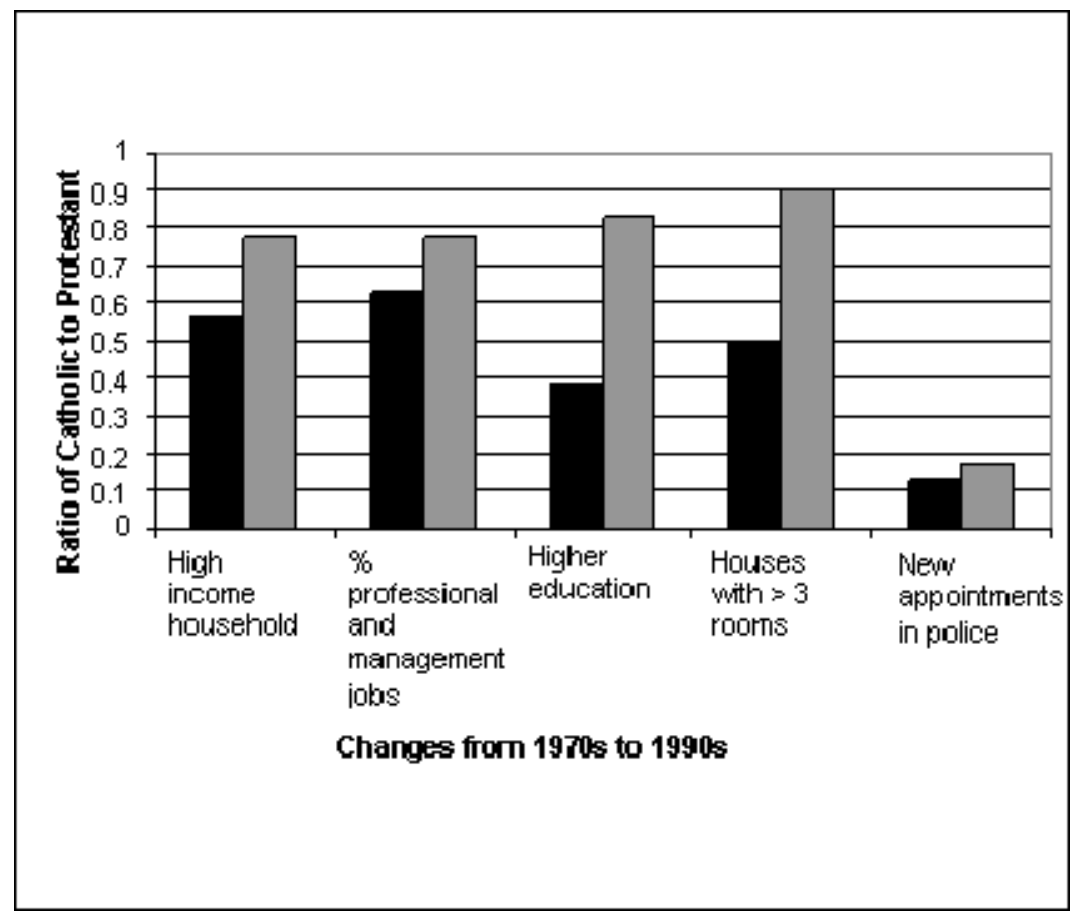


Figure 4: The employment gap in Northern Ireland, men

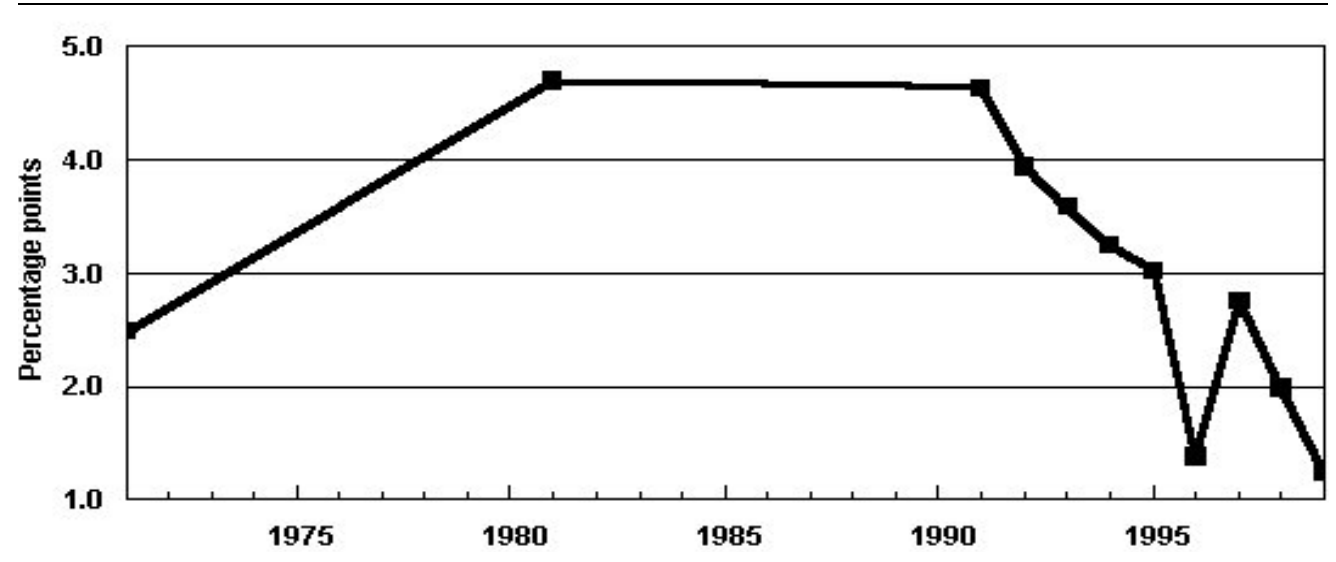

Note: Catholic share of labour force share minus Catholic share of jobs (in percentage points). Source: LFS 1992-99; Census of Population 1971, 1981, 1991

Figure 5: Unemployment rates in Northern Ireland, men

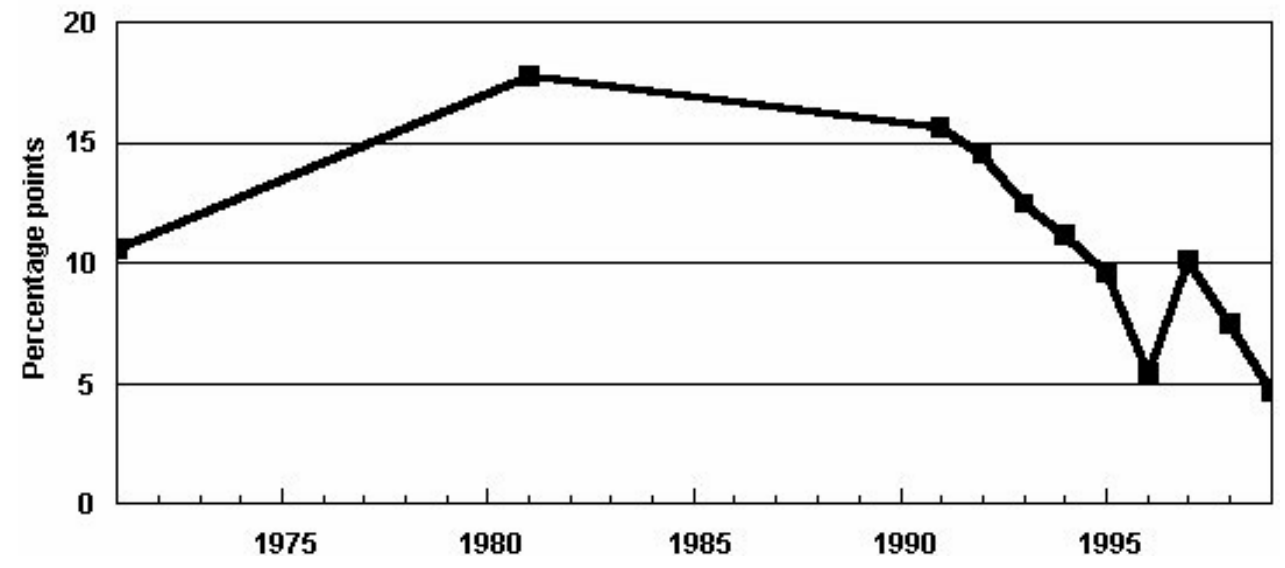

Note: Community differential in unemployment rates: Catholic rate minus Protestant rate (percentage points).

Source: LFS 1992-99; Census of Population 1971, 1981, 1991

The Good Friday Agreement embodied measures to correct political inequalities, such as power sharing and reform of the police to incorporate more Catholics. Police Acts of 1998, 2000, 2003 were passed with the aim of achieving 50 per cent recruitment among Catholics (Osborne and Shuttleworth 2004).

The correction of inequalities appears to have been effective in sustaining the peace process, especially among Catholics. Protestants, who lost by these corrections, continue to show more opposition to the process. There has been an exodus of young Protestants to Britain, and a recent report states that Protestants generally regard themselves as disadvantaged by the peace process, with 39 per cent believing they are worse off than six years ago. Whereas in 1996, 44 per cent of Protestants and 47 per cent of Catholics thought inter-community relationships were better than five years 
previously, in 2003, only 25 per cent of Protestants and 33 per cent of Catholics did (University of Ulster 2003).

\section{Correcting social and economic HIs-a summary}

The survey of affirmative action shows that it often has some success in reducing HIs, but has rarely totally eliminated gaps_although in a few cases (e.g., Northern Ireland and Sri Lanka; see below) selected gaps were even reversed. Moreover, there is no evidence that the policies reduce efficiency, though careful evaluations are rare. In theory, there are reasons for expecting the efficiency impacts to have both negative and positive elements. On the negative side, there is the interference in normal competitive processes which might prevent resources being allocated according to their most efficient use; but on the positive side is the offset (or reduction) in discrimination which itself contributes to inefficient resource allocation, and should allow the greater exploitation of potential. The most systematic study of the efficiency impact has been with respect to US affirmative action towards blacks. Some studies show positive impact, while none show negative. 8 In Malaysia, the high economic growth that accompanied the policies also suggest that the policies are highly unlikely to have had any substantial negative efficiency impact, and may have had positive impact.

Figure 6: GDP in Malaysia and Indonesia

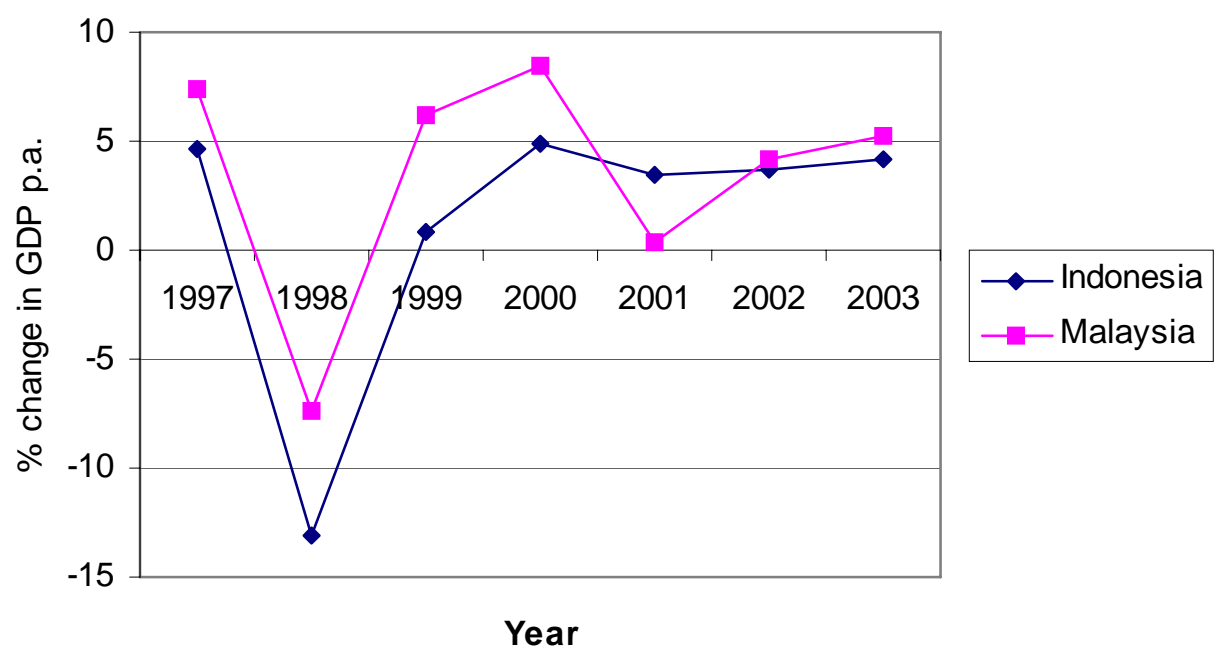

It has been argued that while the policies reduce inter-group inequality they increase intra-group inequality. From an a priori perspective, this is not inevitable but depends on whether the policies mostly extend lower-income opportunities and services (e.g., unskilled employment; investment in poor regions; primary education) or mostly affect upper-income opportunities (professional and skilled employment; higher education). Systematic evidence on this is lacking. In the case of Malaysia, intra-group inequality

8 'the preponderance of evidence suggests that activity associated with equal employment and affirmative action policies is associated with small but significant gains in a range of blue-collar and white-collar occupations'; Simms (1995: 3) summarizing Badgett and Hartmann (1995). 
fell during the decade when the policies were most effective. In South Africa, it is argued that intra-black inequality has risen since the policies were reduced. In both cases, of course, many other influences were simultaneously affecting income distribution (e.g., the anti-poverty policies in Malaysia; and the liberalization policies in South Africa) so the changes cannot be attributed to the affirmative policies alone.

The possibility of adverse impact on efficiency and intra-group equity suggests that one should aim to design policies which tend by themselves (or in conjunction with other policies) to enhance efficiency and to improve income distribution. From an efficiency perspective, this might mean a greater emphasis on process reform and subsidies than quotas; and from an equity perspective, it would mean putting emphasis on employment and basic services, and infrastructure in poor regions.

It should also be noted that even if the policies did reduce efficiency and worsen intragroup income distribution, these effects would need to be weighed against their likely impact in reducing violence, which itself would have positive effect on growth and efficiency and poverty reduction. From this perspective a comparison of Malaysia's post-1997 record with that of Indonesia is suggestive. Both suffered a similar economic shock, which was followed by a period of quite serious violence in the case of Indonesia. While Malaysia's growth was slightly positive, taking the whole period 1997 to 2003 (Figure 6) Indonesia's growth rate was negative, on average, (GDP per capita falling by 5.3 per cent over the period).

\subsection{Political action}

Ensuring that each major group participates in political power is a critical requirement for sustained peace, since political exclusion is likely to generate the leadership which is essential for mobilization. Hence action is needed to reduce political HIs and to ensure that each group participates in political decision-making and power. Where one group dominates numerically in the population (e.g., in Sri Lanka; Northern Ireland; Rwanda), a Westminster majoritarian political system plus winner takes all ensures that minorities are excluded politically. Power sharing is not a natural consequence of the way many understand democracy.

It should be emphasized that political participation can occur at many levels (central, regional, local), in different types of decision (defence, economic, social) and in different activities (army, police, civil service). Full political participation means that significant groups in the population participate across the board, and that their presence is not just nominal. There are many ways this can be promoted. Appendix Tables A.2 and A.3 review a range of such policies which have been introduced in divided societies. Here we touch briefly on major aspects.

- A federal constitution: Where groups are mainly geographically separate a federal constitution can empower different groups. Nigeria is an example. The 
Nigerian case also shows that the design of the federation is also an important factor, as the initial three-state constitution encouraged Biafran separatism. After the civil war the Federation was redesigned to encompass more states which straddled different ethnicities.

- $\quad$ The extent and nature of decentralization: This can contribute to power sharing in a similar way to federalism. This may have been one reason why Bolivia avoided conflict despite deep HIs. But it does not always work in the intended way. Decentralization can replace one set of power brokers by another, which may or may not diffuse group domination. For example, in a study in Northern Sumatra, Indonesia, mayoral election in Medan was achieved with the support of a group of 'toughs'. The poor were not empowered: 'land rights activists argue that local governments which are supposed to be accountable to local peoples have done little to resolve long standing land tenure disputes involving the peasantry; labour activists suggest that party linked militia have been involved in terrorising workers during labour disputes, while in the pay of local industrialists' (Vedi Hadiz 2004: 715). Where groups are geographically concentrated, such decentralization may nonetheless give greater political power to previously underrepresented groups. But it can also lead to continued (or even greater) disempowerment for some (normally minority) groups within the decentralized areas, as is also the case with federalism (cf. Nigeria).

- $\quad$ The voting system: A proportional representation system gives more power to minorities, but even with proportional representation a majority can dominate decision-making unless one also adopts a power-sharing system in elected assemblies and government. Other voting systems (such as the alternative vote) can be designed to improve group representation. Such systems are rare in developing countries, although it is worth reporting that no country with proportional representation has had serious conflict.

- $\quad$ The nature of the elected assemblies: In a two-house, assembly, its possible to combine democratic representation in one house of the assembly with geographic (as in US) or group representation in the other. The voting system within assemblies can be designed to prevent a single group dominating (e.g., requiring a two-thirds majority), or veto powers.

- Seat reservation for particular groups: This has been adopted for the unscheduled castes and tribes in India (and in a number of cases for women).

- Job allocation within government: For example, there is provision for three presidents in Bosnia-Herzegovina. There can be formal or informal provisions for a fair share of political posts at every level: (i) presidential; (ii) cabinet; (iii) senior civil service; (iv) military, and (v) police.

- Citizenship rights: These can be comprehensive covering all who live in an area, or highly restrictive, requiring several generations of residence, or extending only to 'blood' ties with some 'original' inhabitants. By excluding 
people from citizenship rights they may also be excluded from voting, or participation in government (as in Cote d'Ivoire).

- The nature of political parties: If unconstrained, political parties tend to become 'ethnic' in divided societies (Horowitz 1985). For this reason, multiparty elections often provoke violence (Snyder 2000; Stewart and O’Sullivan 1999). Policies towards political parties range from outlawing them altogether (as in Museveni's Uganda) to requiring them to have multiethnic support (e.g., in Nigeria).

- Human rights protection: Strong protection of civil liberties and human rights does not ensure power-sharing. But it does limit the abuse of power. It obviously has an important role to play.

This account has only touched on the many policies that can be used to ensure political participation of major groups. As with economic and social policies, there has been considerable experience in designing political systems to achieve inclusive and balanced political participation in sharply divided societies struggling to maintain peace and cohesion. Among developed countries, Belgium and Switzerland are prime examples. Many developing countries initially overcame these problems by one-party authoritarian regimes which suppressed dissent. But the political issues associated with multiethnic societies are coming to the fore with democratization. The recommended formula of majoritarian multiparty democracy is not adequate and post-conflict countries have struggled to find alternative more inclusive models. Nigeria, Fiji, Ethiopia and Malaysia are examples, each having modified their political systems as a consequence of political unrest. It is clear that policies to address political HIs need to accompany economic and social policies in post-conflict situations if renewed conflict is to be avoided.

\subsection{Cultural policies}

Cultural policies can be an important aspect of group grievances and consequently of post-conflict policies_such policies aim to correct cultural exclusion and discrimination (e.g., policies towards language, religious ceremonies, religious or ethnic dress, national holidays and so on. Language has been a critical issue in many countries, including Sri Lanka and among the Kurds in Iraq. Ceremonies and symbols are also important, at least as triggers for conflict: the Orange parades in Northern Ireland and the site of religious buildings in India and Israel/Palestine are among many examples. Dimitrijevics (2004) argues that in peace negotiations policies towards such cultural aspects have been more important for promoting peace than either political or economic policies.

\section{Do current reconstruction policies include policies towards HIs?}

At a general level, it seems that concern with correcting HIs is not part of the policy mix advocated by major donors. On the economic side, reconstruction policies have been mainly addressed towards restoring the infrastructure and (re)establishing a market 
economy, including the introduction of the normal package of liberal market reforms. On the political side, the emphasis has been on multi-party democracy and the 'usual' governance reforms, i.e. improved transparency and accountability.

... [the] peace building 'template' has come to include concrete programs and projects such as civil society promotion, multi-party elections, constitutionalism, rule of law and minority rights, gender equality, good governance through transparency and accountability, economic liberalization, and security sector reform'. Tschirgi (2004: 14)9

The World Bank Report, Breaking the Conflict Trap, argues that in general appropriate policy should be different in post-conflict countries from normal peacetime policies. In particular the Report argues for policies to help post-conflict countries sustain growth, to offset the impact of commodity price slumps, to increase transparency in natural resource rich economies, and to limit access to resources which finance conflict. It does not consider any policies towards HIs. Actual practice in post-conflict reconstruction is more telling than broad prescriptions.10 To assess this, I investigate two casesMozambique and Guatemala — where HIs seem to have been an important factor behind the conflict.

\section{Reconstruction and HIs in Mozambique and Guatemala}

\subsection{Mozambique}

Mozambique suffered a bitter civil war following independence. Although the war was ideological and geo-political with the socialist Frelimo government being attacked by the more conservative forces of Renamo with strong support from South Africa and some from the US, there were underlying regional and ethnic differences between the parties. There were also systematic inherited horizontal inequalities between these ethnicities/regions and the conflict was almost certainly partly due to the relative deprivation in the areas represented by Frelimo.

More than ten years have followed since the 1992 peace agreement and several multiparty elections. Reconstruction efforts received strong international support, which

9 This broadly represents the thrust of the 1995 DAC Guidelines 'Helping Prevent Violent Conflict' which places it chief emphasis on the need for policy coordination; it emphasizes the need to incorporate local actors into decision making (including civil society), for gender balance. The importance of socioeconomic disparities is recognized, but not linked to ethnic dimensions, nor incorporated systematically into policy.

10 Boyce (2002) presents a very useful survey of policies adopted in selected countries post-conflict, showing that they are little different from normal adjustment policies. He points to the need to raise taxation and expenditure post-conflict, and mentions disparities but says but says very little about policies towards them. 
were rather successful from the perspective of growth and poverty reduction (albeit interrupted by natural disasters, including floods and drought). Yet the policies in no way addressed the underlying horizontal inequalities, which have persisted. The case illustrates how existing approaches to reconstruction often fail to incorporate an HI dimension into their thinking. Continued neglect of HIs may again undermine political stability. A fierce internal conflict between Frelimo and Renamo followed after Mozambique became independent in 1975. The division between these parties was primarily regional-with Frelimo being mainly a Southern party and Renamo for the most part representing the Centre. The North was divided between the two. This regional division also reflected ethnic divisions-Frelimo was supported by the Xitsonga (accounting for 24.1 per cent of Mozambique population) from the Southern region, and Renamo had Cisena (27 per cent of the population) and Ndau support from the central region- indeed Frelimo has been described as an 'Ndau project'. A UNnegotiated peace agreement ended the fighting in 1992, and multiparty general elections followed in 1994 and 1999-in a first past the post-system Frelimo won each election easily.

Although the civil war had strong ideological elements and was also due to extensive external intervention, 'ethnicity, particularly the perceived dominance of state power by southerners' played an important role in shaping Mozambique’s civil conflict'. (Manning 2002: 44).

Table 3: Horizontal inequalities, Mozambique, 1997

\begin{tabular}{lccc}
\hline & Xitsonga & Cisena & $\begin{array}{c}\text { Ratio of } \\
\text { Xitsonga:Cisena }\end{array}$ \\
\hline \% of households with: electricity & 19.6 & 8.3 & 2.36 \\
$\quad$ television & 13.4 & 3.1 & 4.32 \\
$\quad$ refrigerator & 12.1 & 2.4 & 5.04 \\
\% women attended school & 68.2 & 55.1 & 1.17 \\
\% husbands with 'modern' occupation & 24.6 & 22.4 & 1.10 \\
IMR & 84.0 & 111.9 & $1.33^{*}$ \\
\% children with health card & 79.2 & 67.2 & 1.18 \\
\hline
\end{tabular}

Note: *inverse of ratio.

Source: Østby (2003).

Table 4: The party split in Mozambique's 1994 elections

\begin{tabular}{lcc}
\hline Region & \% of seats won by Frelimo & Ratio of Frelimo to Renamo \\
\hline North & 50 & 1.0 \\
Centre & 32 & 0.47 \\
South & 92 & 11.5 \\
Aggregate seats & 129F:112R & 1.2 \\
\hline
\end{tabular}

Source: Manning (2002: 171). 
The coincidence of pre-existing regional disparities in economic development, Frelimo's tendency to place government officials in positions away from their home areas (and especially to put southerners in positions of authority in the center and the north), along with the disastrous social and economic consequences of the combination of instantaneous decolonization and transformative socioeconomic policy, made for a readily mobilizable constituency with common problems that displaced Frelimo former leaders could link to ethno-regional bias (Manning 2002: 85).

The conflict, therefore, was able to capitalize 'on existing grievances within Mozambique. Foremost among these were a sense of ethnic and regional domination (by southern groups against the center and center-north)' (Manning 2002: 38). Economic and social horizontal inequalities in Mozambique-whether expressed in ethnic or regional terms - had been entrenched during the colonial period, and were evident in the immediate post-war situation. In Table 3, these HIs are estimated by the ratios of Xitsonga to Cisena resources and consumption. As can be seen Xitsonga (southerners) consistently outperform Xistongas from the centre.

Post-conflict political divisions continued to reflect the war-time divisions, albeit in a peaceful electoral way. Political support for the two parties has consistently followed regional lines. In 1994, each party polled over 75 per cent of their votes in heartland areas. The Frelimo government is supported by the south and part of the north. and the opposition leadership comes mainly from the centre and the north.

The post-conflict political system involves a directly elected president, with considerable powers, including the appointment of the cabinet. The legislature is elected by proportional representation-this is nonetheless dominated by Frelimo who get support from more than half the population. To the extent that that support remains solid because of the way ethnic groupings vote, Renamo and its supporters will continue to lack power. The Frelimo government has used its position to monopolize formal power: for example, the power of traditional leaders, who tend to support Renamo, has been sharply reduced. The President refused to appoint Renamo nominated governors for central provinces which Renamo had won electorally both in 1994 and 1999. As a Frelimo party leader noted, 'The leadership of the government was with people from the south...' (quoted in Manning 2002: 47). The situation is reflected in complaints from Renamo supporter that Nampula was neglected: 'it is a superiority complex of the south over the north' (quoted in Manning 2002: 34) 'what we want is that tribalism, humiliation and segregation of our people ... be stopped'.

In the post-conflict era, both political and economic/social HIs continued, with no attempts to correct them which may partly reflect this political domination, although aid-donors have huge power accounting for three-quarters of government expenditure. 
Post-conflict reconstruction policies included the adoption of IFI-sponsored structural adjustment programmes and considerable amounts of bi- and multilateral aid to support reconstruction (see Brück 2001; Addison 2003). HIs were not considered explicitly in these policies.

The regional distribution of post-war expenditure gives an indication of whether HIs were taken into account in post-conflict policies. A systematic bias favouring the South can be observed (Table 5). Southern households received considerably above average infrastructural benefits of every kind, and the centre did worst, apart from school building where it did a better than the north. Data for aid distribution (which financed much of this infrastructure) also showed a strong bias towards the south. 1997. Average per capita aid disbursements for 1995-97 were US\$18.5 in the north, US\$71.87 in the centre and US\$103.98 in the south (UNDP 1998).

Table 5: Per cent of households in villages benefiting from rehabilitation or construction of infrastructure post-war

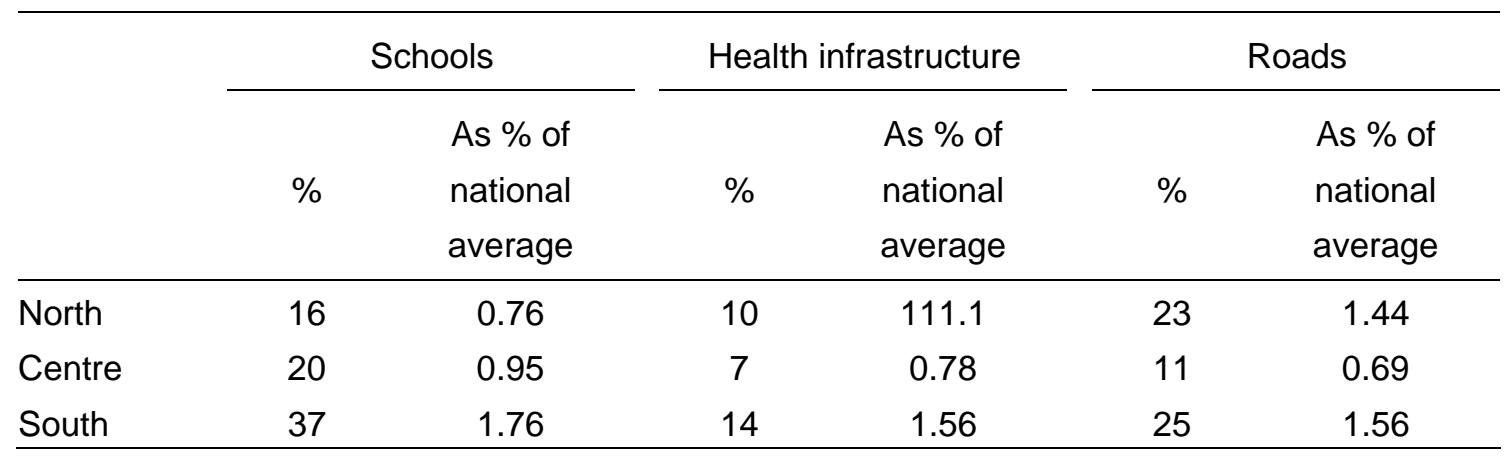

Source: Heltberg et al. (2004) from 1996-97 survey.

Table 6: Regional growth rates, 1996-2000

\begin{tabular}{lccc}
\hline & Annual growth rate GDP, 1996-2000, \% & \multicolumn{2}{c}{ Relative to national average } \\
\cline { 3 - 4 } & & $1996-99$ & $1996-2000^{*}$ \\
\hline North & 8.5 & 1.06 & 1.04 \\
Centre & 6.0 & 0.88 & 0.73 \\
South & 9.5 & 1.07 & 1.16 \\
\hline
\end{tabular}

Note: *south and centre affected by floods, 2000.

Source: UNDP (2001).

One estimate suggests that the centre received just 66 per cent of the average benefits from health and education (1996-97), the north 71 per cent, the south excluding Maputo 89 per cent and Maputo 533 per cent (Helberg et al. 2004). This seems to have continued, with the north and the south expanding their overall share of executed provincial expenditure according to the 2003 PRSP. There was also an imbalance in growth rates, as shown in Table 6. The Mozambique case shows how little HIs are taken into account in current reconstruction efforts-in this case, either with respect to politics 
or economic and social reconstruction. Despite this there has been little threat of the resumption of war, although there have been occasional clashes (such as in November 2000). This is probably for several reasons. First, despite imbalances high growth rates were recorded in all areas, and all areas enjoyed improved infrastructure. Hence the imbalances were less provocative than they would have been in a context of economic stagnation. Second, external support for conflict disappeared. And third, it seems that some elite bargaining takes place in private providing economic opportunities to the leaders of the otherwise powerless opposition.11 Nonetheless, continued political and economic HIs may threaten future stability, particularly if the economic success comes to an end.

\subsection{Post-conflict in Guatemala12}

In Guatemala, sharp HIs have long been evident between indigenous peoples and the European and mixed population, and were an important element in provoking and sustaining the long civil war in Guatemala. Indigenous people account for at least 43 per cent of the population, but boundaries are uncertain and other estimates are higher. Large HIs emerged historically from the colonial experience, and have endured; e.g., for literacy, 1989, the indigenous rate was 10.2 per cent, and the non-indigenous, 76 per cent. According to a UNDP study of Guatemala, there are significant disparities in levels of development between the country's 22 administrative departments with the departments, where most of the country's Maya indigenous population is concentrated, all in the low human development (HDI under 0.500) category, while Guatemala City, where non-indigenous people are concentrated, is in the high human development category. Over three-quarters of the indigenous people live in poverty compared with 41 per cent of the non-indigenous; indigenous people account for 58 per cent of the poor and 72 per cent of the extreme poor. Inequality in land ownership is extreme (Figure 7). In 1979, 2.1 per cent of holdings accounted for 64.5 per cent of the agrarian land (a worsening compared with the 1950s). These economic inequalities were accompanied by extreme political inequalities with power concentrated in the hands of the nonindigenous population.

The historical causes of the long civil war relate to the 'exclusionary, racist, authoritarian and centralist characteristics of the state, economy and Guatemalan society’ (CEH 1999: 81, quoted in Caumartin). In a coup in 1954 a reformist regime was overthrown (with the support of the US, sections of the military and the elite). Subsequently, guerrilla resistance to the new regime emerged, led by non-indigenous rebel soldiers. The initial movement was rapidly suppressed, but new ones emerged, mostly with non-indigenous leadership, but with strong indigenous support. There

11 'Renamo seeks to gain outside the formal system what it cannot win through formal competition' (Manning 2002: 215).

12 This section draws heavily on Caumartin (2004). 
followed a brutal campaign of state terror, with indigenous people being the main victims. Six hundred and twenty-two separate massacres were recorded by the UN sponsored truth commission. The war finally came to an end through a negotiated peace agreement between the government and the guerrilla umbrella movement. It was negotiated over nine years in three rounds of talks, ending in 1996. Altogether 17 separate accords were agreed. Of these, the first six were mainly concerned with procedures for securing peace; subsequently, there were three agreements on human rights, one specifically related to indigenous peoples and one establishing a commission to investigate human rights abuses; two of the agreements concerned socioeconomic issues, one related to resettlement and one to the agrarian question; the remainder covered constitutional issues and peace-making.

From our perspective the two most relevant accords are the Agreement on the SocioEconomic aspects and the Agrarian situation and the Agreement on the Identity and Rights of Indigenous Peoples (AIRI). The main provisions of the first were to increase tax revenue in order to support increased social expenditure; to introduce a register for land tenure and a trust fund to buy underused land for redistribution to tenant farmers; and conflict resolution mechanisms for land disputes. Each of these provisions in principle should help correct HIs, the first HIs in public entitlements to social services, and the second in land-both very serious aspects of HIs and exclusion in Guatemala.

The AIRI also potentially involved substantial correction of HIs (including cultural aspects). It included recognition of the identity of indigenous peoples, elimination of discrimination against them and the guarantee of the cultural, civil, political and social and economic rights of indigenous peoples. There was a commitment to ratify the ILO convention 169, the most extensive international convention for the protection of indigenous peoples rights; and the establishment of several joint commissions (of government and indigenous representatives) to develop specific proposals. These commissions include educational reform and cultural diversity, making indigenous languages official, protecting indigenous religious sites, political reform, participation and culture , indigenous women, indigenous peoples' land rights and customary law. As Caumartin notes, 'if adequately implemented, the AIRI provide the blueprint for a radical transformation of the Guatemalan state as well as a new starting point for interethnic relations' (2004: 58).

Nonetheless, many considered the agreement did not go far enough in this direction. However, its implementation proved even weaker. A political campaign against the agreements developed among conservative forces, with strong media support. It was argued that the agreement had been 'forced' on Guatemala by external forces. A referendum on the agreements was held in 1998. The 'no' campaign argued that approval would 'convert Guatemala into an indigenous state, marginalising the nonindigenous', that 'citizens would be divided and that the indigenous would possess more rights than other citizens' (Liga-Pro Patria leaflet cited in Caumartin 2004: 62); that non 
indigenous would lose their jobs; and that Guatemala might become 'balkanized'. In the referendum, the 'nos' won by 55 per cent to 45 per cent on a poll of only 18.6 per cent of the electorate. A breakdown of voting patterns shows that indigenous districts voted overwhelmingly in favour, and non-indigenous ones against (Jonas 2000).

Subsequently, according to Caumartin 'most accords bar those that dealt with the strict mechanics of the cease fire have either floundered or been subjected to substantial delays during the implementation phase. Key sections ... are currently in limbo (agrarian issues, indigenous rights, the redefinition of the mandate of the armed forces and the overhaul of the tax system)' (2004: 63-64). A record of peace-monitoring indicators shows some progress, but many targets have not been met (Table 7).

While progress has been made on education (spending and outcomes), tax revenue has risen less than targeted and so has GDP, so that government revenue is well below that targeted. Health expenditure has risen less than targeted and health outcomes are substantially below target. Overall, however, government expenditure on human development has risen from 3.1 per cent of GDP to 5 per cent from 1997 to 2001, and some key services (electricity, education, access to water) have been targeted towards Mayan groups (UNDP 2001). The HDI has risen for both indigenous and nonindigenous between 1989 and 2002, and there has been some narrowing of the gap between indigenous and non-indigenous (from 0.72 per cent for indigenous as a percentage of non-indigenous to 0.81 per cent).

A key failure was that land reform was not tackled. In 1979, the smallest farms accounted for 88 per cent of the number of farms but just 16.2 per cent of the land. The number of small farms had risen to 92.1 per cent by 2003 and their share of land to 21.9 per cent. On average large farms had 145 times the land per farm of small farms in 1979. There was a slight improvement by 2003, but large farms were still on average 131 times the size of small farms.

Table 7: Selected peace monitoring indicators in Guatemala

\begin{tabular}{lccc}
\hline \multicolumn{1}{c}{ Target } & Base 1995 & Target 2000 & Actual 2000 \\
\hline Growth rate, \% p.a. & 6 & 6 & 3.3 \\
Tax revenues, \% of GDP & 7.6 & 12 & 9.6 \\
Education spending, \% of GDP & 1.6 & 2.5 & 2.5 \\
Health spending, \% of GDP & 0.9 & 1.3 & 1.1 \\
Military spending, \% GDP & 1 & 0.7 & 0.7 \\
Judiciary spending, \% GDP & 0.2 & 0.3 & 0.5 \\
Literacy rate, \% & 64.2 & 70 & 68.9 \\
IMR, per 1,000 life births & 40 & 20 & $40-45$ \\
Maternal mortality rate, per 100,000 births & $97-270^{*}$ & 48.5 & $190-270^{*}$ \\
\hline
\end{tabular}

Note: * First figure, World Bank (2000); second figure, WHO.

Source: World Bank/Guapa (2003: 39). 
The Guatemalan case is very different from that of Mozambique. In the Guatemalan case, atypically, some of the deep problems related to HIs were included in the initial agreements. Even so if the agreements were fully to tackle HIs they would have needed to be interpreted with progressive imagination and determination. In the event, however, strong political resistance, and apathetic efforts on the part of the government meant that progress was mixed, although probably sufficient to prevent conflict breaking out again on the part of the indigenous community. Since much of the responsibility for the conflict was in fact that of the elite/military in their vicious attacks on the indigenous communities, ironically the rather limited progress towards improving HIs may in fact have contributed to peace, by giving this elite little grounds for overturning the government as they had done before.

Figure 7: Land distribution in Guatemala

Lorenz curves: land distribution

Gini (1979) $=0.78$; Gini $(2003)=0.73$

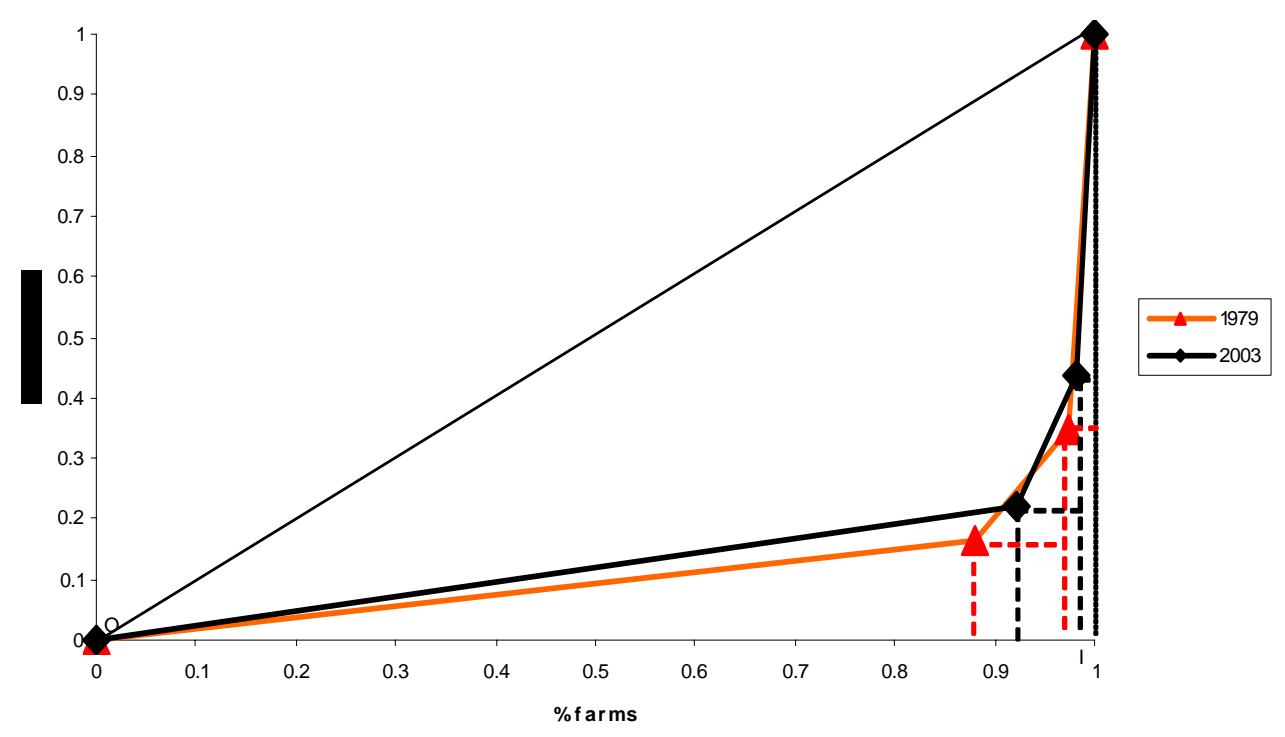

In general, the elite have done extremely well out of the peace accords, politically as well as economically: the military have been dislodged from power and the non-military elite is again a dominant political actor-for example in the Arzu government of 19962000; and the 2004 Berger administration. Consequently, the elite have a powerful incentive not to overthrow the government. However, insecurity remains very high, taking the form of high of very high levels of criminality, involving one of the highest homicide rates in the world which indicates that while the accords may have ended the civil war, violent conflicts remain a dominant characteristic of Guatemalan society. Long standing high HIs may also play an important role in these new patterns of conflict and violence. 


\section{Conclusions}

This paper has reviewed policies appropriate for correcting HIs in post-conflict countries. It has emphasized that policies need to correct political as well as economic and social HIs, although which policies are appropriate depends on the context. In general, policies to correct economic and political HIs do not seem to feature in most post-conflict policy recommendations, nor in practice. It must be re-emphasized that these are not the only policies needed. Policies to assist the resumption of economic growth and the reconstruction of economic and social infrastructure are also needed as well as policies to promote demobilization. Particular emphasis is needed on promoting unskilled employment, since lack of employment among young men is a common feature of conflict economies, a factor which predisposes to conflict.

I would conclude with three cautions. The first is the often argued point that affirmative actions tend to 'entrench' ethnicity. It should be pointed out that this is most likely to be a feature of policies involving targets and quotas, not those related to process and Human Rights, so this is an argument for prime emphasis on the latter type of policies. But there are places where HIs are so deep that more positive policies involving targets etc. are required. In practice, such policies are generally required in situations where are ethnicities are already entrenched. If accompanied by cultural and educational policies to promote multiethnic cohesion, they need not entrench ethnic consciousness further than it is already. In Malaysia, for example, while it has been argued that ethnicity has been entrenched by the policies, inter-marriage has remained high and collaborative ventures across ethnic lines have increased. In Malaysia, also the policies are being phased out as it is considered that their major objectives have been achieved. Continuous review and a time limited approach is generally desirable.

Figure 8: Changing inequalities in Sri Lanka

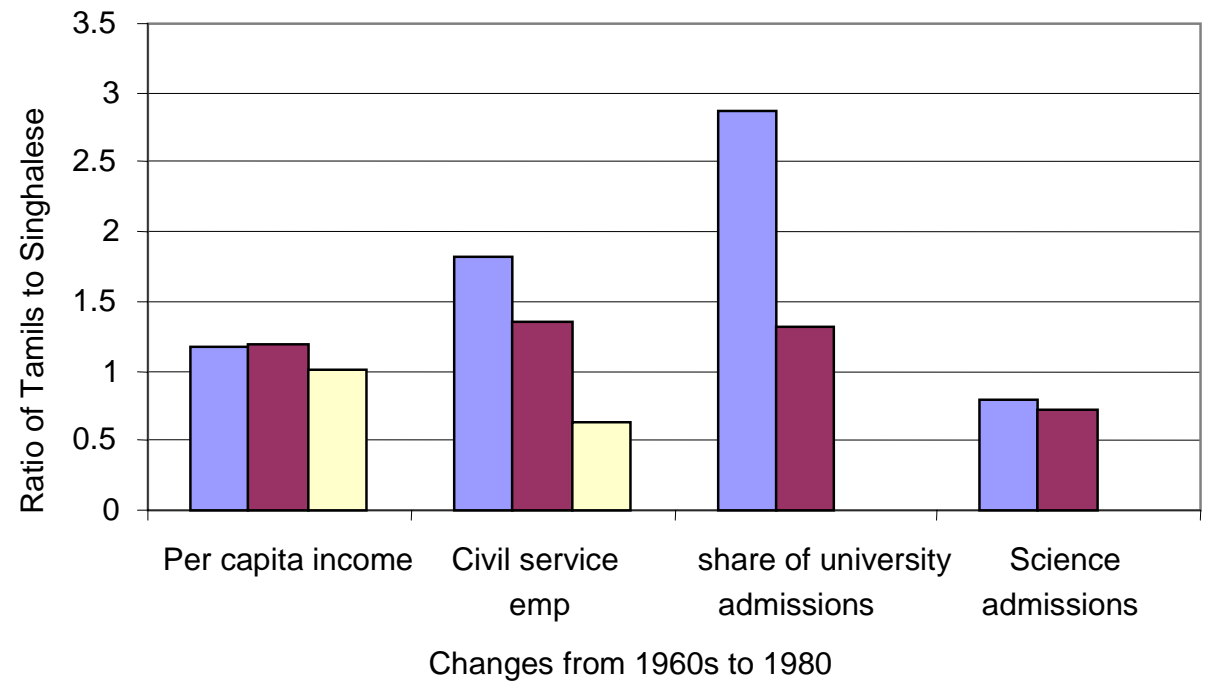


The second caution is that in certain circumstances the policies themselves may provoke violence. Indeed, it has been argued that this was the case in Sri Lanka. Colonial preferences had given the minority Tamil community disproportionate presence in government and higher education. To counter this, the Sinhalese majority introduced some severe measures to reverse the position, including making Sinhalese the national language and that of government, and introducing strict quotas on university entrance. There were also discriminatory land policies. These measures had the effect of reversing the previous dominance of Tamils in government and substantially reducing their advantages in the universities (see Figure 8). High levels of unemployment among the educated youth, virtually no prospect of political power in a majoritarian system (even with proportional representation which was eventually introduced) provided an incentive for young educated Tamils to lead a violent separatist rebellion (Sriskandarajah 2000).

The case powerfully shows the need to be cautious in introducing policies to correct HIs so as not to provoke violent reaction from those who are losing some privileges. However, in this case, other factors were also present-including provocative language policies and high levels of unemployment among educated youths. Elsewhere inequalities have been moderated if not reversed without provoking violent reaction (e.g., in Trinidad and Tobago) 13 in addition to the cases of Northern Ireland and Malaysia mentioned above.

The third caution is illustrated by the example of Guatemala. Where the privileged dominate the political system, they may not be willing to implement corrective policies, whatever the international pressure to do so. In such situations, there is little the international community can do, other than through their own aid budgets. The implication again is that action to correct political HIs may need to precede economic action-but of course this is easier to say than to do, though when conflicts come to an end the peace negotiations provide an occasion in which comprehensive political participation and economic balance can and should be discussed.

While then policies to correct HIs may meet difficulties, the more the consideration of group inequality becomes part of the norms of policy-making in peace-time as well as post-conflict situations, the more likely that action towards HIs will become part of routine policy-making as well as in the post-conflict situation.

13 Sriskandarajah (2005). 


\section{References}

Addison, T. (ed.) (2003). From Conflict to Recovery in Africa, Oxford University Press for UNU-WIDER: New York.

Alexander, J.M. (2003). 'Inequality, Poverty and Affirmative Action: Contemporary Trends in India', paper prepared for the UNU-WIDER conference on Inequality, Poverty and Human Well-being, 30-31 May, Helsinki.

Alexander, A., and K. Jacobsen (1999). 'Affirmative Action: A Critical Reconnaissance'. International Journal of Urban and Regional Research 23(3): 593601.

Amos, T., and R. Scott (1996). 'Perceptions of Affirmative Action: An Empirical Study’, South African Journal of Business Management 27(3): 5-58.

André, C., and J.-P. Platteau (1996). Land Tenure under Unendurable Stress: Rwanda Caught in the Malthusian Trap, Centre de Recherche en Economie du Développement (CRED), Facultés universitaires Notre-Dame de la Paix: Namur.

Auvinen, J., and E.W. Nafziger (1999). 'The Sources of Humanitarian Emergencies', Journal of Conflict Resolution 43: 267-90.

Badgett, M.V.L., and H.L. Hartmann (1995). 'The Effectiveness of Equal Employment Opportunity Policies', in M.C. Simms (ed.), Economic Perspectives on Affirmative Action, University Press of America: Lanham MD.

Badgett, M.V.L., W.M. Rogers, D.L. Williams, T. Larson, W. Thomas, M. Garrett, and P. Sirola (1997). 'The Impact of Affirmative Action on Public Sector Employment and Contracting in California', available at: www.ucop.edu/cprc/ong.html.

Banerjee, A., and R. Somanathan (2001). 'Caste, Community and Collective Action: The Political Economy of Public Good Provision in India', available at www: econwww.mit.edu/faculty/download_pdf.php?id=524.

Barr, K.J. (2001). 'Racism in the Pacific', paper prepared for the World Council of Churches Ecumenical Study on Racism, April, available at www.ecrea.org.fj/webpages/publications_files/Papers/13.doc.

Boyce, J.K. (2002). Investing in Peace: Aid and Conditionality after Civil Wars, The International Institute for Strategic Studies: London.

Brück, T. (2001). 'Coping with Peace: Post-war Household Strategies in Northern Mozambique', paper prepared for UNU-WIDER conference on Debt Relief, 17-18 August, Helsinki.

Chand, S. (1997). 'Ethnic Conflict, Inequality and Growth in Independent Fiji', available at http://rspas.anu.edu.au/melanesia/Chand.htm.

Chua, A. (2003). World on Fire, Heinemann: London. 
Collier, P., and A. Hoeffler (2000). 'Greed and Grievance in Civil War', World Bank Policy Research Department Working Paper 2355, World Bank: Washington DC.

Collier, P. (2003). Breaking the Conflict Trap: Civil War and Development Policy, Oxford University Press for the World Bank: New York.

Darity, W., J. Dietrich, and D. Gulkey (1997). 'Racial and Ethnic Inequality in the United States: A Secular Perspective’, African-American Economic Gains 87(2): 301-5.

Darby, J. (1999). 'Northern Ireland: Beyond the Time of Troubles', in C. Young (ed.), The Accommodation of Cultural Diversity, Macmillan: London.

Dimitrijevics, A. (2004). 'Integrating Patterns of Conflict Resolution. A Group Oriented Approach to the Study of the Genesis and Dynamics of Conflict', PhD thesis, University of Oxford: Oxford.

Donohue, J., and J. Heckman (1991). 'Continuous versus Episodic Change: The Impact of Civil Rights Policy on the Economic Status of Blacks', Journal of Economic Literature 29: 1603-43.

Duflo, E. (no date). 'Decentralization and Political Reservations in India: Some Evidence', available at www//econ.ucsd.edu/seminars/Duflo\%20USCD_ presentation.pdf

Drogin, B. (1996). 'Why Africa is Harder', IPI Report April/May: 18-28.

Eide, A. et al. (eds) (1992). The Universal Declaration of Human Rights: A Commentary, Scandinavian University Press: Oslo, and Oxford University Press: Oxford.

Galanter, M. (1984). Competing Equalities: Law and the Backward Classes in India, University of California Press: Berkeley CA.

Gove, J. (2000). 'Economic Freedom Continues to Elude South Africa's Blacks', available at journalism.berkeley.edu/projects/safrica/adapting/affirmative.html.

Guillebeau, C. (1999). 'Affirmative Action in a Global Perspective: The Cases of South Africa and Brazil', Sociological Spectrum 19: 443-65.

Hadiz, V. (2004). 'Decentralization and Democracy in Indonesia: a Critique of NeoInstitutionalist Perspectives’, Development and Change 35(4): 697-718.

Heltberg, R., K.R. Simler, and F. Tarp (2004). 'Public Spending and Poverty in Mozambique', in T. Addison, H. Hansen, and F. Tarp (eds), Debt Relief for Poor Countries, Palgrave Macmillan for UNU-WIDER: Basingstoke.

Hepburn, A.C. (1983). 'Employment and Religion in Belfast, 1901-1951', in R.J. Cormack and R.D. Osborne (eds), Religion, Education and Employment: Aspects of Equal Opportunity in Northern Ireland, Appletree: Belfast. 
Holsti, K. (2000). 'The Political Sources of Humanitarian Disasters', in E.W. Nafziger, F. Stewart, and R. Väyrynen (eds), The Origin of Humanitarian Emergencies, Oxford University Press for UNU-WIDER: Oxford.

Holzer, H.J., and D. Neumark (1998). 'What Does Affirmative Action Do?', NBER Working Paper 6605, National Bureau of Economic Research: Cambridge MA.

Homer-Dixon, T. (1994). 'Environmental Scarcities and Violent Conflict: Evidence from Cases’, International Security 19(1): 5-40.

Horowitz, D. (1985). Ethnic Groups in Conflict, University of California Press: Berkeley.

Htun, M. (2003). 'Why Identity Groups Get Represented in Politics', available at www.newschool.edu/gf/polsci/seminar/Htun9-25-03.pdf.

ILO (2003). Time for Equality at Work, International Labour Organization: Geneva.

Jain, H.C., and C.S. Venkata Ratnam (1994). 'Affirmative Action in Employment for the Scheduled Castes and the Scheduled Tribes in India', International Journal of Manpower 15(7): 6-25.

Jauch, H.M. (1998). Affirmative Action in Namibia: Redressing the Imbalances of the Past?, New Namibia Books: Windhoek.

Jomo K.S. (2001). 'Malaysia’s New Economic Policy and “National Unity”', paper presented at the UNRISD United Nations World Conference Against Racism, Xenophobia and Related Forms of Intolerance, 3-4 September, Durban.

Keen, D. (1994). The Benefits of Famine: a Political Economy of Famine Relief in Southwestern Sudan 1883-1989, Princeton University Press: Princeton NJ.

Manning, C.L. (2002). The Politics of Peace in Mozambique: Post-Conflict Democratization, 1992-2000, Praeger: Westport CT.

McKittrick, D. (2004). 'Catholics on March in Northern Ireland as Protestants Leave', The Independent, 18 May.

Melber, H. (2003). 'Of Big Fish and Small Fry: The Fishing Industry in Namibia', Review of African Political Economy 30(95): 142-9.

Nafziger, E.W., and J. Auvinen (2002). 'Economic Development, Inequality, War and State Violence’, World Development 30(2): 163-70.

OECD (2001). The DAC Guidelines: Helping Prevent Violent Conflict, OECD: Paris.

Osborne, R., and I. Shuttleworth (eds) (2004). Fair Employment in Northern Ireland: A Generation On, Blackstaff Press: Belfast.

Østby, G. (2003). Horizontal Inequalities and Civil War, Norwegian University of Science and Technology: Oslo. 
Pande, R. (2003). 'Can Mandated Political Representation Increase Policy Influence for Diadvantaged Minorities?’, American Economic Review 93(4): 1132-51.

Ratuva, S. (2002). 'Economic Nationalism and Communal Consolidation: Economic Affirmative Action in Fiji, 1987-2002', Pacific Economic Bulletin 17(1): 130-7.

Ruane, J., and J. Todd (1996). The Dynamics of Conflict in Northern Ireland, Cambridge University Press: Cambridge.

Schultz, T.P., and G. Mwabu (1998). 'Labor Unions and the Distribution of Wages and Employment in South Africa', Industrial and Labor Relations Review 51(4): 680708.

Seenarine, M. (1996). 'Dalit Women: Victims or Beneficiaries of Affirmative Action Policies in India: A Caste Study', paper presented at a conference at the Southern Asian Institute, Colombia University, 10 April, New York.

Simms, M.C. (ed.) (1995). Economic Perspectives on Affirmative Action, University Press of America: Lanham MD.

Snyder, J.L. (2000). From Voting to Violence: Democratization and Nationalist Conflict, Norton: New York and London.

Sowell, T. (1990). Preferential Policies: An International Perspective, William Morrow: New York.

Sriskandarajah, D. (2000). 'The End of Serendipity: Politico-Economic Explanations of Ethnic Conflict in Sri Lanka’, PhD thesis, University of Oxford: Oxford.

Sriskandarajah, D. (2005). 'Development, Inequality and Ethnic Accommodation: Clues from Malaysia, Mauritius and Trinidad and Tobago', Oxford Development Studies 33(2): 195-210.

Stewart, F., and M. O’Sullivan (1999). 'Democracy, Conflict and Development: Three Cases', in G. Ranis, S.-C. Hu, and Y.-P. Chu (eds), The Political Economy of Comparative Development into the 21st Century, Essays in Memory of John C.H. Fei, Edward Elgar: Cheltenham.

Tilly, C. (1998). Durable Inequality, University of California Press: Berkeley CA.

Tschirgi, N. (2004). Post-conflict Peacebuilding Revisited: Achievements, Limitations and Challenges, International Peace Academy: New York.

Turton, D. (1997). 'War and Ethnicity: Global Connections and Local Violence in North East Africa and Former Yugoslavia'. Oxford Development Studies 25(1): 7794.

UNDP (1998). Development Cooperation Report 1995-1997, UNDP: Maputo.

Ukiwo, U. (2004). 'Policy Levers in Nigeria', CRISE Policy Context Paper 2, University of Oxford: Oxford. 
UNDP (1997). 'Fiji: Poverty Report', UNDP and Government of Fiji: Suva.

University of Ulster (2003). Northern Ireland Life and Times Survey, University of Ulster: Belfast.

UNDP (no date). 'Affirmative Action Policies: An International Perspective', UNDP: New York.

UNRISD (2004). 'Ethnic Structure, Inequality and Governance of the Public Sector', available at: www.unrisd.org .

Walsh, C. (2000). 'Poverty, Politics and the Politics of Race in Fiji', paper prepared for DevNet Conference, available at: www.devnet.org.nz/conf/Papers/walsh.pdf.

Wood, C., and P. Lovell (1992). 'Racial Inequality and Child Mortality in Brazil', Social Forces 70(3): 703-24.

World Bank (2002). 'Poverty in India: The Challenge of Upper Pradesh', World Bank: Washington DC, available at: www//lnweb18.worldbank.org/sar/sa.nsf/ Attachments/UPPov-c4/\$File/Chapter4.pdf.

Yusof, Z.A. (2001). 'Income Distribution in Malaysia', in C. Barlow (ed.) Modern Malaysia in the Global Economy: Political and Social Change into the Twenty-first Century, Edward Elgar: London. 
Table A1: Examples of economic/social affirmative action

\begin{tabular}{|c|c|c|c|c|c|c|c|c|}
\hline & & & & & \multicolumn{4}{|c|}{ Consequences } \\
\hline & \multicolumn{2}{|l|}{ Group categories } & Prior group inequality & Nature of action & HIs & Intra-group inequality & Special problems & Political \\
\hline $\begin{array}{l}\stackrel{\bar{N}}{\frac{\Delta}{\Delta}} \\
\frac{\Delta}{\infty}\end{array}$ & $\begin{array}{l}\text { Whites } \\
\text { Blacks and } \\
\text { mixed race } \\
\text { (mostly mixed race) }\end{array}$ & $\begin{array}{l}54 \% \\
45 \%\end{array}$ & $\begin{array}{l}\text { Income/education/empl. } \\
\text { favoured whites, plus many } \\
\text { other inequalities. 1960-88 } \\
\text { worsening HIs. }\end{array}$ & $\begin{array}{l}\text { Some measures in 1990s. } \\
\text { From 2001, reservation of } \\
\text { proportion of govt. job } \\
\text { training, government } \\
\text { employment, university } \\
\text { places, mainly favouring } \\
\text { blacks. }\end{array}$ & $\begin{array}{l}\text { Too soon to tell, but could } \\
\text { be at expense of mixed } \\
\text { race. }\end{array}$ & Too soon to tell & Fuzzy group boundaries & $\begin{array}{l}\text { Programmes presented } \\
\text { discreetly. Too soon to } \\
\text { assess political } \\
\text { consequences. }\end{array}$ \\
\hline$\overline{\bar{T}}$ & $\begin{array}{l}\text { Indigenous Fijans } \\
\text { Indo-Fijans }\end{array}$ & $\begin{array}{l}51 \% \\
43 \%\end{array}$ & $\begin{array}{l}\text { Average income of Indo- } \\
\text { Fijans above indigenous; } \\
\text { but poverty worse among } \\
\text { Indo-Fijans. } \\
\text { Fijans dominate govt } \\
\text { employment and land } \\
\text { ownership. } \\
\text { Indo-Fijans dominate private } \\
\text { sector. }\end{array}$ & $\begin{array}{l}\text { Measures favour } \\
\text { indigenous Fijans, } \\
\text { including, restrictions on } \\
\text { land ownership, loan } \\
\text { schemes, equity schemes, } \\
\text { support for small enterprise, } \\
\text { reservation of some sectors, } \\
\text { privatization. }\end{array}$ & $\begin{array}{l}\text { Not much evidence. } \\
\text { Sharp HIs remain in some } \\
\text { areas (e.g. corporate } \\
\text { management). }\end{array}$ & $\begin{array}{l}\text { Agreement that have } \\
\text { enriched indigenous } \\
\text { elite/middle class. } \\
\text { Very slow economic growth. }\end{array}$ & & $\begin{array}{l}\text { An element behind } \\
\text { successive coups whenever } \\
\text { Indo-Fijans get power } \\
\text { because fear elimination of } \\
\text { programmes. } \\
\text { Together with political } \\
\text { situation, responsible for } \\
\text { emigration of Indo-Fijans. }\end{array}$ \\
\hline 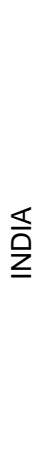 & $\begin{array}{l}\text { SCs } \\
\text { STs } \\
\text { OBCs }\end{array}$ & $\begin{array}{l}16 \% \\
8.5 \% \\
\text { na }\end{array}$ & $\begin{array}{l}\text { Backward groups } \\
\text { substantially below } \\
\text { average in incomes, } \\
\text { consumption, land } \\
\text { ownership, education, etc. }\end{array}$ & $\begin{array}{l}\text { Variety of educational, } \\
\text { land and public sector job } \\
\text { reservations. }\end{array}$ & $\begin{array}{l}\text { Evidence of small } \\
\text { positive impact on public } \\
\text { investment, and incomes. } \\
\text { Large improvements in } \\
\text { education. }\end{array}$ & $\begin{array}{l}\text { Has permitted a small } \\
\text { segment of backward } \\
\text { castes to move into middle } \\
\text { class, but exclusion and } \\
\text { abject poverty remains for } \\
\text { most. No evidence of } \\
\text { negative efficiency impact. }\end{array}$ & $\begin{array}{l}\text { Difficult to assess how far } \\
\text { improvements are due to } \\
\text { programmes and how far } \\
\text { to 'modernization' and } \\
\text { growth. }\end{array}$ & $\begin{array}{l}\text { Has to be assessed } \\
\text { together with strong political } \\
\text { programmes. May have } \\
\text { entrenched rather than } \\
\text { reduced caste differences. } \\
\text { Triggered riots in Bihar, } \\
\text { 1978; and several times in } \\
\text { Gujerat in 1980s. General } \\
\text { rise in violence against SCs } \\
\text { has been attributed to } \\
\text { programmes. }\end{array}$ \\
\hline
\end{tabular}




\begin{tabular}{|c|c|c|c|c|c|c|c|c|}
\hline $\begin{array}{l}\frac{4}{0} \\
\frac{17}{5} \\
\frac{5}{5} \\
\frac{1}{2}\end{array}$ & $\begin{array}{l}\text { Bumiputeras } \\
\text { Chinese } \\
\text { Indians }\end{array}$ & $\begin{array}{l}63 \% \\
30 \% \\
8 \%\end{array}$ & $\begin{array}{l}\text { Incomes of Chinese more } \\
\text { than } 2 \text { times Bumiputeras, } \\
\text { 1970; and Indians } 75 \% \\
\text { more. }\end{array}$ & $\begin{array}{l}\text { Range of measures, } \\
\text { including education, land } \\
\text { ownership, govt } \\
\text { employment, share } \\
\text { ownership, to improve } \\
\text { Bumiputera position }\end{array}$ & $\begin{array}{l}\text { Reduction in HIs in } \\
\text { education, incomes, } \\
\text { corporate ownership, but } \\
\text { quite large HIs remain in } \\
\text { incomes/assets. } \\
\text { Educational differences } \\
\text { being eliminated. }\end{array}$ & $\begin{array}{l}\text { May have increased intra- } \\
\text { Bumiputera inequality- } \\
\text { although not much } \\
\text { evidence. Inequality overall } \\
\text { reduced. Accompanied by } \\
\text { very high growth. }\end{array}$ & & $\begin{array}{l}\text { No recurrence of anti- } \\
\text { Chinese riots of } 1969 \\
\text { including in the } 1997 \text { crisis } \\
\text { when such riots occurred in } \\
\text { Indonesia. } \\
\text { May have increased ethnic } \\
\text { consciousness and } \\
\text { entrenchment. }\end{array}$ \\
\hline 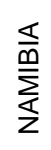 & $\begin{array}{l}\text { Black Africans } \\
\text { Whites }\end{array}$ & $\begin{array}{l}95 \% \\
5 \%\end{array}$ & $\begin{array}{l}\text { Very large HIs on all } \\
\text { dimensions at } \\
\text { independence (1990) }\end{array}$ & $\begin{array}{l}\text { Action on employment, } \\
\text { land, loans, education }\end{array}$ & $\begin{array}{l}\text { Improvements in public } \\
\text { employment. Much less } \\
\text { elsewhere. }\end{array}$ & $\begin{array}{l}\text { Black middle class } \\
\text { benefited most. }\end{array}$ & $\begin{array}{l}\text { Market model limits } \\
\text { transformation. }\end{array}$ & \\
\hline 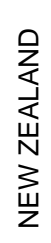 & $\begin{array}{l}\text { NZ European } \\
\text { Maori }\end{array}$ & $\begin{array}{r}74.5 \% \\
9.7 \%\end{array}$ & $\begin{array}{l}\text { Significant HIs in every } \\
\text { dimension }\end{array}$ & $\begin{array}{l}\text { Support for Maori business } \\
\text { and skills; and education. }\end{array}$ & $\begin{array}{l}\text { Improvement in HIs in } \\
\text { employment and education. } \\
\text { Gaps much lower than in } \\
\text { Canada or Australia. }\end{array}$ & & & \\
\hline 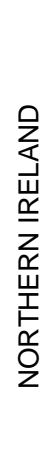 & $\begin{array}{l}\text { Protestants } \\
\text { Catholics }\end{array}$ & $\begin{array}{l}53 \% \\
44 \%\end{array}$ & $\begin{array}{l}\text { Catholics in worse position } \\
\text { than Protestants in jobs, } \\
\text { education, housing, police }\end{array}$ & $\begin{array}{l}\text { From } 1976 \text { successive } \\
\text { fair Employment Acts/ } \\
\text { Orders and other } \\
\text { government action } \\
\text { applying to private as well } \\
\text { as public sector. }\end{array}$ & $\begin{array}{l}\text { Reduction in HIs in all } \\
\text { dimensions, although gaps } \\
\text { remain. } \\
\text { Share of Catholics in } \\
\text { 'monitored' private sector } \\
\text { employment rose from } 35 \% \\
\text { (1990) to } 41 \% \text { (2002). } \\
\text { Bigger improvement in } \\
\text { public sector. } \\
\text { In education Catholics } \\
\text { overtaking Protestants. }\end{array}$ & $\begin{array}{l}\text { Poverty levels above the } \\
\text { UK, worse for Catholics } \\
\text { Vertical inequality high. }\end{array}$ & & $\begin{array}{l}\text { Narrowing Hls likely to be } \\
\text { behind peace process. } \\
\text { But Protestants increasingly } \\
\text { resentful; and argue that } \\
\text { they are discriminated } \\
\text { against which may present } \\
\text { problems for political } \\
\text { progress. }\end{array}$ \\
\hline 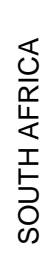 & $\begin{array}{l}\text { Black Africans } \\
\text { Coloured } \\
\text { Whites }\end{array}$ & $\begin{array}{r}73 \% \\
9 \% \\
14 \%\end{array}$ & $\begin{array}{l}\text { At end of apartheid, huge } \\
\text { HIs in incomes, assets, } \\
\text { employment, education, } \\
\text { land. }\end{array}$ & $\begin{array}{l}\text { Action in employment, } \\
\text { assets, education. }\end{array}$ & $\begin{array}{l}\text { Some improvement in HIs, } \\
\text { but large differentials } \\
\text { remain. } \\
\text { Most improvement in } \\
\text { public sector employment. }\end{array}$ & $\begin{array}{l}\text { Increased intra-black } \\
\text { inequality. } \\
\text { Unemployment and poverty } \\
\text { levels among blacks very } \\
\text { high. }\end{array}$ & $\begin{array}{l}\text { Dominant market model } \\
\text { restricts effectiveness of } \\
\text { action, especially on assets. }\end{array}$ & $\begin{array}{l}\text { Black/white political } \\
\text { relations appear good. } \\
\text { High levels of criminality. } \\
\text { Potential political problems } \\
\text { possible without faster } \\
\text { progress. }\end{array}$ \\
\hline
\end{tabular}




\begin{tabular}{|c|c|c|c|c|c|c|c|c|}
\hline $\begin{array}{l}\frac{\nwarrow}{2} \\
\frac{1}{\leq} \\
\frac{\bar{x}}{\omega}\end{array}$ & $\begin{array}{l}\text { Sinhalese } \\
\text { Tamils } \\
\text { Moslems }\end{array}$ & $\begin{array}{r}74 \% \\
19 \% \\
7 \% \\
\end{array}$ & $\begin{array}{l}\text { Colonial power favoured } \\
\text { Tamils in education } \\
\text { and civil service. } \\
\text { Average incomes of } \\
\text { Tamils a bit higher than } \\
\text { Singhalese }\end{array}$ & $\begin{array}{l}\text { Action on education and } \\
\text { civil service (incl. requiring } \\
\text { Sinhalese language to be } \\
\text { used). } \\
\text { State sponsored settlement } \\
\text { of Sinhalese in land } \\
\text { previously occupied by } \\
\text { Tamils. }\end{array}$ & $\begin{array}{l}\text { HIs changed sharply. } \\
\text { In civil service employment } \\
\text { now favoured Sinhalese. } \\
\text { Incomes of Sinhalese rose } \\
\text { and Tamils fell, with former } \\
\text { exceeding latter }\end{array}$ & & $\begin{array}{l}\text { Situation exacerbated } \\
\text { by slow growth in } \\
\text { employment. }\end{array}$ & \begin{tabular}{|l|} 
Reaction of Tamils to \\
action was major factor \\
behind civil war, and Tamil \\
demands for independence \\
of North East.
\end{tabular} \\
\hline 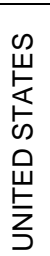 & $\begin{array}{l}\text { Whites } \\
\text { Blacks }\end{array}$ & $\begin{array}{l}82 \% \\
13 \%\end{array}$ & $\begin{array}{l}\text { Large HIs in incomes, } \\
\text { education, health, assets, } \\
\text { etc. }\end{array}$ & $\begin{array}{l}\text { Action in education, } \\
\text { employment and housing }\end{array}$ & Small reduction in His & $\begin{array}{l}\text { Increase in intra-black } \\
\text { inequality. } \\
\text { No evidence of negative } \\
\text { efficiency impact, from } \\
\text { numerous studies, and } \\
\text { some found positive effects }\end{array}$ & & $\begin{array}{l}\text { Black riots (high incidence in } \\
\text { 1970s) have stopped. } \\
\text { Political and legal reaction } \\
\text { from whites, challenging } \\
\text { action. }\end{array}$ \\
\hline
\end{tabular}

Notes: SCs $=$ Scheduled castes. STs $=$ Scheduled tribes. OBCs $=$ Other backward castes.

Sources:

Brazil: Guillebeau (1999), Silva (1992), and Wood and Lovell (1992).

Fiji: UNDP (1997), Horsecroft (2002), Barr (2001), Walsh (2000), Reddy et al. (2001), Chand (1997), and Ratuva (2002).

India: Mandelsohn and Vicziany (1998), Alexander (2003), Duflo (no date), Banerjee and Somanathan (2001), Jauch (1998), World Bank (2002), Pande (2003), UNDP (no date),

Mendelsohn and Vicziany (1998), Galanter (1984), Parry (1999), Jain and Ratnam (1994), and Seenraine (1996).

Malaysia: Yusof (2001).

Namibia: World Bank (1991), Jauch (1998), and Melber (2003).

Northern Ireland: ILO (2003), Alexander and Jacobsen (1999), and Darby (1997).

South Africa: Eide et al. (1992), Alexander and Jacobsen (1999), Gove (2000), Amos and Scott (1996), Drogin (1996), Collins (1994), and Schultz and Mwabu (1998).

Sri Lanka: Sowell (1990), and Sriskandarajah (2000).

United States: Holzer and Neumark (1998), Donohue and Heckman (1994), Badgett et al. (1997), and Darity, Dietrich and Gulkey (1997). 
Appendix Table A2: Political actions

\begin{tabular}{|c|c|c|c|c|c|c|c|c|c|c|c|}
\hline Country & Ethnicity & & $\begin{array}{l}\text { Official } \\
\text { language }\end{array}$ & Nature of state & Voting & Political parties & Government & Veto rights & Civil service & Conflict & Consequences \\
\hline 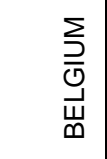 & $\begin{array}{l}\text { Flemish } \\
\text { Walloon } \\
\text { Mixed or other }\end{array}$ & $\begin{array}{l}58 \% \\
31 \% \\
11 \%\end{array}$ & bilingual & $\mid \begin{array}{l}\text { Federal } \\
2 \text { regions, } \\
10 \text { provinces }\end{array}$ & $\begin{array}{l}\text { Proportional } \\
\text { representation }\end{array}$ & Mainly ethnic & Fixed ratios & $\begin{array}{l}\text { De facto on } \\
\text { big issues } \\
\text { (2/3 majority) }\end{array}$ & Fixed ratios & Avoided & $\begin{array}{l}\text { Entrench ethnic } \\
\text { identities }\end{array}$ \\
\hline 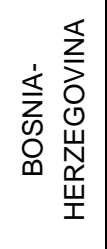 & $\begin{array}{l}\text { Serb } \\
\text { Bosniak } \\
\text { Croat } \\
\text { Others } \\
(2000)\end{array}$ & $\begin{array}{l}37.1 \% \\
48 \% \\
14.3 \% \\
0.6 \%\end{array}$ & $\begin{array}{l}\text { Serbian } \\
\text { Croatian } \\
\text { Bosnian }\end{array}$ & $\begin{array}{l}\text { Federal } \\
\text { two first-order } \\
\text { administrative } \\
\text { divisions and one } \\
\text { internationally } \\
\text { supervised district }\end{array}$ & $\begin{array}{l}\text { Proportional } \\
\text { representation }\end{array}$ & $\begin{array}{l}\text { Some ethnic; } \\
\text { some national }\end{array}$ & Power-sharing & De facto & $\begin{array}{l}\text { 'Equitable } \\
\text { representation' }\end{array}$ & $\begin{array}{l}\text { Avoided to date } \\
\text { (international military } \\
\text { presence) }\end{array}$ & $\begin{array}{l}\text { Entrench } \\
\text { identities plus } \\
\text { bureaucratization }\end{array}$ \\
\hline 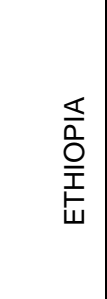 & $\begin{array}{l}\text { Oromo } \\
\text { Amhara \& Tigre } \\
\text { Sidamo }\end{array}$ & $\begin{array}{l}40 \% \\
32 \% \\
9 \%\end{array}$ & $\begin{array}{l}\text { Amharic } \\
\text { Right of } \\
\text { each group } \\
\text { to use own } \\
\text { language }\end{array}$ & $\begin{array}{l}\text { Ethnic Federalism } \\
\text { (9 ethno-based } \\
\text { states). } \\
\text { States right } \\
\text { to secession. }\end{array}$ & $\begin{array}{l}\text { Majoritarian, } \\
\text { boundaries drawn } \\
\text { on ethnic lines. } \\
\text { Reserved seats for } \\
\text { minorities. }\end{array}$ & $\begin{array}{l}\text { Some national; } \\
\text { some ethnic }\end{array}$ & $\begin{array}{l}\text { Proportional representation } \\
\text { of ethnicities at each level } \\
\text { of govt. }\end{array}$ & & $\begin{array}{l}\text { Aim for } \\
\text { proportional } \\
\text { representation in } \\
\text { all branches of } \\
\text { govt. }\end{array}$ & $\begin{array}{l}1995 \text { constitution } \\
\text { designed to avoid } \\
\text { conflict, after long } \\
\text { Eritrea war for } \\
\text { independence. } \\
\text { Border war with } \\
\text { Eritrea, 1998-2000. }\end{array}$ & \\
\hline 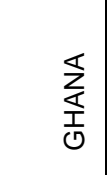 & $\begin{array}{l}\text { Akan (fragmented) } \\
\text { Mole Dagbani } \\
\text { Ewe } \\
\text { Ga }\end{array}$ & $\begin{array}{c}49.1 \% \\
16.5 \% \\
12.7 \% \\
8 \%\end{array}$ & English & $\begin{array}{l}\text { Unitary with } \\
\text { provisions to curb } \\
\text { ethnic polarization; } \\
\text { decentralization }\end{array}$ & Majoritarian & $\begin{array}{l}\text { Ethnic parties } \\
\text { prohibited }\end{array}$ & $\begin{array}{l}\text { No formal arrangements- } \\
\text { informal balance }\end{array}$ & No & Informal sharing & Major conflict avoided & \\
\hline 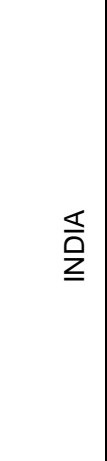 & $\begin{array}{l}\text { Hindu } \\
\text { (SCs \& STs } \\
\text { Muslim }\end{array}$ & $\begin{array}{l}81.3 \% \\
24.5 \%) \\
12 \%\end{array}$ & Hindi & $\begin{array}{l}\text { Federal } \\
28 \text { states and } \\
7 \text { union territories }\end{array}$ & Majoritarian & $\begin{array}{l}\text { Some national; } \\
\text { some ethnic }\end{array}$ & $\begin{array}{l}\text { Quotas for SCs and STs in } \\
\text { state legislatures and lower } \\
\text { house of parliament, and } \\
\text { some reservations for } \\
\text { women in village } \\
\text { panchayats women, not } \\
\text { Moslems. } \\
\text { Token representation of } \\
\text { Moslems. } \\
\text { SCs and STs not } \\
\text { represented at high levels. }\end{array}$ & No & $\begin{array}{l}\text { Quotas for STs and } \\
\text { SCs in civil service, } \\
\text { but level not } \\
\text { specified. }\end{array}$ & $\begin{array}{l}\text { Sporadic of various } \\
\text { kinds; especially } \\
\text { Hindi/Moslem }\end{array}$ & $\begin{array}{l}\text { Political position } \\
\text { of SCs/STs } \\
\text { seems to have } \\
\text { improved } \\
\text { economic } \\
\text { position }\end{array}$ \\
\hline
\end{tabular}




\begin{tabular}{|c|c|c|c|c|c|c|c|c|c|c|c|}
\hline 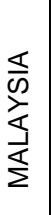 & $\begin{array}{l}\text { Bumiputeras } \\
\text { Chinese } \\
\text { Indians }\end{array}$ & $\begin{array}{r}62 \% \\
27.8 \% \\
9.6 \%\end{array}$ & $\begin{array}{l}\text { Bahasa } \\
\text { Melayu }\end{array}$ & Federation & $\begin{array}{l}\text { Majoritarian, but } \\
\text { with informal } \\
\text { agreements to } \\
\text { assure ethnic } \\
\text { representation }\end{array}$ & Mainly ethnic. & $\begin{array}{l}\text { Ethnic corporatism, } \\
\text { assured by national } \\
\text { coalition (Barisan national) } \\
\text { with Malays dominating } \\
\text { through UMNO }\end{array}$ & No & Malay dominated & Avoided since 1969 & \\
\hline $\begin{array}{l}\overleftarrow{c} \\
\stackrel{্}{W} \\
\frac{0}{Z}\end{array}$ & $\begin{array}{l}\text { Hausa } \\
\text { Yoruba } \\
\text { Igbo }\end{array}$ & $\begin{array}{r}21 \% \\
20 \% \\
-17 \%\end{array}$ & English & $\begin{array}{l}\text { Federation, with } \\
\text { increasing number } \\
\text { of states (36) } \\
\text { reducing likelihood } \\
\text { of conflict. }\end{array}$ & Majoritarian & $\begin{array}{l}\text { Ethnic } \\
\text { elements, } \\
\text { though some } \\
\text { national } \\
\text { representation } \\
\text { required. }\end{array}$ & $\begin{array}{l}\text { Federal character } \\
\text { principle requires some } \\
\text { representation from across } \\
\text { country }\end{array}$ & Informal only & $\begin{array}{l}\text { Federal character } \\
\text { means } \\
\text { representation } \\
\text { from over the } \\
\text { country, but over } \\
\text { representation of } \\
\text { Southern and under } \\
\text { representation of } \\
\text { Northern. }\end{array}$ & $\begin{array}{l}\text { Many relatively minor } \\
\text { conflicts. No national } \\
\text { conflict since Biafran } \\
\text { war } 1967-70 .\end{array}$ & \\
\hline 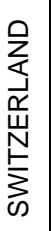 & $\begin{array}{l}\text { German } \\
\text { French } \\
\text { Italian }\end{array}$ & $\begin{array}{r}73.4 \% \\
20.5 \% \\
4.1 \%\end{array}$ & Three & $\begin{array}{l}\text { Federation } \\
26 \text { cantons }\end{array}$ & \begin{tabular}{|l|} 
Proportional \\
representation plus \\
direct democracy \\
(referenda)
\end{tabular} & $\begin{array}{l}\text { Mainly national } \\
\text { (ideological) }\end{array}$ & Power sharing & $\begin{array}{l}\text { Veto via } \\
\text { referenda }\end{array}$ & Shared. & No conflict & $\begin{array}{l}\text { Women only } \\
\text { recently } \\
\text { enfranchised }\end{array}$ \\
\hline
\end{tabular}

Notes: SCs = Scheduled castes (in India). STs = Scheduled tribes (in India). UMNO = United Malays National Organization.

Source: UNRISD (2004), Ukiwo (2004), Htun (2003), The Federal Elements of the 1995 Ethiopian Constitution. 
Appendix Table A3: Other countries with some political affirmative action

\begin{tabular}{|c|c|c|c|}
\hline Country & Ethnicity & Affirmative action & History of violent conflict \\
\hline Bhutan & $\begin{array}{l}\text { Bhote } 50 \% \\
\text { ethnic Nepalese } 35 \% \\
\text { indigenous or migrant tribes } \\
15 \% \text {. } \\
\text { Lamaistic Buddhist } 75 \% \\
\text { Indian- and Nepalese- } \\
\text { influenced Hinduism } 25 \%\end{array}$ & $\begin{array}{l}\text { 10/150 seats reserved for } \\
\text { Buddhists }\end{array}$ & $\begin{array}{l}\text { Some border conflicts with } \\
\text { India because Maoist } \\
\text { Assam separatists located } \\
\text { on border }\end{array}$ \\
\hline Colombia & $\begin{array}{l}\text { mestizo } 58 \% \\
\text { white } 20 \% \\
\text { mulatto } 14 \% \\
\text { black } 4 \% \\
\text { mixed black-Amerindian } 3 \% \\
\text { Amerindian } 1 \%\end{array}$ & $\begin{array}{l}2 \text { seats for Afro- } \\
\text { Colombians; } \\
3 \text { seats for Indians in } \\
\text { Senate out of } 102 \text { seats }\end{array}$ & $\begin{array}{l}\text { Long-standing conflict over } \\
\text { land. }\end{array}$ \\
\hline Croatia & $\begin{array}{l}\text { Croat } 89.6 \% \\
\text { Serb } 4.5 \%\end{array}$ & $\begin{array}{l}\text { Seats reserved for ethnic } \\
\text { minorities }\end{array}$ & $\begin{array}{l}\text { Fighting for independence } \\
\text { from Yugoslavia, 1991-5. }\end{array}$ \\
\hline Cyprus & $\begin{array}{l}\text { Greek } 85.2 \% \\
\text { Turkish } 11.6 \%\end{array}$ & $\begin{array}{l}\text { Seats reserved for Turks, } \\
\text { Maronite, Roman Catholic } \\
\text { and Goumenian minorities, } \\
\text { but only Greek seats filled. }\end{array}$ & $\begin{array}{l}\text { Conflict between Greeks } \\
\text { and Turks for control from } \\
\text { 1974. Island divided. }\end{array}$ \\
\hline Ethiopia & $\begin{array}{l}\text { Oromo } 40 \% \\
\text { Amhara and Tigre } 32 \% \\
\text { Others } 28 \%\end{array}$ & $\begin{array}{l}\text { 22/117 seats reserved for } \\
\text { minorities }\end{array}$ & $\begin{array}{l}\text { Revolutionary war ended } \\
\text { 1991. Eritrea boundary war } \\
\text { ended } 2000 .\end{array}$ \\
\hline Jordan & $\begin{array}{l}\text { Sunni Muslim 92\% } \\
\text { Christian 6\% }\end{array}$ & $\begin{array}{l}12 / 110 \text { reserved for } \\
\text { Christians }\end{array}$ & None \\
\hline Lebanon & $\begin{array}{l}\text { Muslim } 70 \% \text { (including } \\
\text { Shi'a, Sunni, Druze, } \\
\text { Isma'ilite, Alawite or } \\
\text { Nusayri) } \\
\text { Christian 30\% }\end{array}$ & $\begin{array}{l}\text { Quotas for particular groups } \\
\text { for } 101 / 128 \text {. }\end{array}$ & $\begin{array}{l}16 \text { year civil war ended } \\
1991 .\end{array}$ \\
\hline
\end{tabular}




\begin{tabular}{|c|c|c|c|}
\hline Country & Ethnicity & Affirmative action & History of violent conflict \\
\hline Mauritius & $\begin{array}{l}\text { Indo-Mauritian 68\% } \\
\text { Creole } 27 \% \\
\text { Hindu } 52 \% \\
\text { Christian } 28.3 \% \text { (Roman } \\
\text { Catholic } 26 \% \text {, Protestant } \\
2.3 \%) \\
\text { Muslim } 16.6 \%\end{array}$ & 8/70 for minorities. & None \\
\hline $\begin{array}{l}\text { New } \\
\text { Zealand }\end{array}$ & $\begin{array}{l}\text { New Zealand European } \\
74.5 \% \\
\text { Maori } 9.7 \%\end{array}$ & $7 / 120$ for Maoris & None \\
\hline Niger & $\begin{array}{l}\text { Hausa 56\% } \\
\text { Djerma 22\% } \\
\text { Fula } 8.5 \% \\
\text { Tuareg 8\% }\end{array}$ & $8 / 83$ for minorities & $\begin{array}{l}5 \text { year Tuareg insurgency } \\
\text { ended 1995. Several coups } \\
\text { subsequently. }\end{array}$ \\
\hline Pakistan & $\begin{array}{l}\text { Punjabi, Sindhi, Pashtun } \\
\text { (Pathan), Baloch, Muhajir }\end{array}$ & $\begin{array}{l}\text { 10/342 of Lower House } \\
\text { reserved for minorities }\end{array}$ & Recurring conflicts \\
\hline Samoa & Samoan $92.6 \%$ & $\begin{array}{l}\text { 2/49 seats reserved for part } \\
\text { and non-Samoans }\end{array}$ & None \\
\hline Venezuela & $\begin{array}{l}\text { European and (small) } \\
\text { indigenous population }\end{array}$ & 3 seats reserved for Indians & None \\
\hline
\end{tabular}

Source: Htun (2003), CIA (World Fact Book). 